\title{
The Akademia Zamojska: Shaping a Renaissance University
}

\section{Universities in the Polish-Lithuanian Commonwealth}

In the course of the sixteenth century, in the territory initially under the jurisdiction of Poland and, from 1569 on, of the Polish-Lithuanian Commonwealth, three centres of higher education were established that could boast the status of university.

The first to be founded, in 1544, was the academy of Königsberg, known as the Albertina after the first Duke of Prussia, Albert of Hohenzollern. In actual fact, like other Polish gymnasia established in what was called Royal Prussia, the dominant cultural influence over this institution, was German, although the site purchased by the Duke on which it was erected was, at the time, a feud of Poland. ${ }^{1}$ It was indeed from Sigismund I I Augustus of Poland that the academy received the royal privilege in 1560, approval which - like the papal bull that was never actually issued - was necessary for obtaining the status of university. However, in jurisdictional terms at least, the university was Polish for only one century, since from 1657 it came under direct Prussian control. It went on to become one of the most illustrious German institutions, attracting academics of international and enduring renown including the philosophers Immanuel Kant and Johann Gottlieb Fichte. The Albertina was conceived as an emanation of the University of Marburg and consequently the teaching body was strictly Protestant, headed by its first rector, the poet and professor of rhetoric Georg Sabinus (1508-156o), son-in-law of Philip Melanchthon. When it opened, the university numbered many Poles and Lithuanians among its students, ${ }^{2}$ and some of its most eminent masters were also Lithuanian, such as the professor of Greek and Hebrew

1 Karin Friedrich, The Other Prussia (Cambridge, Cambridge University Press, 2000), 20-45, 72-74. The most celebrated schools in the territory of Royal Prussia included the gymnasia of Gdańsk, Elbląg and Torun. On these, and more generally on the relation between Reformation and education in the Polish-Lithuanian Commonwealth in the Early Modern age, see the recent essay by Michael Tworek, "Education: The Polish-Lithuanian Commonwealth," in Howard Louthan and Graeme Murdock (eds.), A Companion to the Reformation in Central Europe (Leiden-Boston: Brill, 2015), 359-389.

2 Theodor Wotschke, “Polnische und Litauische Studenten in Königsberg," Jahrbücher für Kultur und Geschichte der Slaven 6, no. 1 (January 1930): 428-447. 
Abraham Kulwieć (Abraomas Kulvietis, 1509-1546) and Stanisław Rafajłowicz (Stanislovas Rapolionis), professor of theology and famous for his translations into Polish of various works, including a Protestant version of the Bible commissioned by Duke Albert of Prussia. Following the Reformed and Melancthonian approach, Aristotle was studied purged of the scholastic interpretations, with teaching concentrating in particular on the study of dialectic understood as an instrument to be used in medical, juridical and theological debate. ${ }^{3}$

About twenty-five years after the foundation of this Reformation stronghold, the Academia et Universitas Vilnensis was established by the Jesuits in Vilnius in Lithuania. It initially began operation as a college in 1570, and the key figure in its promotion to a university was the humanist Stanisław Hozjusz (1504-1579), who managed to persuade the upper echelons of the Society, Pope Gregory XIII and the then sovereign Stephen Báthory of the need for a school of Jesuit learning in the region. ${ }^{4}$ Officially founded in 1579 , it was modelled on the Roman College and - up to the middle of the seventeenth century - comprised only the two faculties of theology and philosophy. Although the philosophy faculty had numerous chairs, including metaphysics, logic, ethics and mathematical sciences, the most developed and renowned field of studies was theology. ${ }^{5}$ All the rectors of the institution came from the Jesuit ranks and, at

3 To date there is no systematic study on the influence of Polish culture in the early decades of the academy's activity. However a detailed description of the intellectual life of the institution can be found in several studies by Marco Sgarbi: "Aristotelismo a Königsberg (1544-1740)," in Logica e metafisica nel Kant precritico: ambiente intellettuale di Königsberg e la formazione filosofica kantiana (Frankfurt a. M.: P. Lang, 2010), and Kant and Aristotle. Epistemology, Logic, and Method (New York: suny Press, 2016). See also Götz von Selle, Geschichte der AlbertusUniversität zu Königsberg im Preussen (Würzburg: Holzner, 1956).

4 Ludwik Piechnik, Dzieje Akademii Wileńskie: Początki Akademii Wileńskiej, 1570-1599 [History of the Vilnius Academy, 1570-1599: The beginnings of the Vilnius Academy], Tom I (Rome: Institutum Historicum Societatis Jesu, 1983), 26-27. In general, see Stanisław Obirek, Jezuici w Rzeczypospolitej Obojga Narodów w latach 1564-1668. Dziatalność religijna, spotecznokulturalna i polityczna [The Jesuits in the Republic of the Two Nations in the years 1564-1668. Religious, socio-cultural and political activity] (Kraków: Wydział Filozoficzny Towarzystwa Jezusowego, 1996); also important are the contributions of Roman Darowski addressing Jesuit teaching in the field of philosophy and including general descriptions of the creation and organisation of the Jesuit schools. See, for example, Filozofia w szkotach jezuickich w Polsce w XVI wieku (Teksty istudia) [Philosophy in the Jesuit schools of Poland in the sixteenth century (texts and studies)] (Kraków: Fakultet Filozoficzny Towarzystwa Jezusowego, 1994); Studies in the Philosophy of the Jesuits in Poland in the 16th to 18th Centuries (Kraków: 'Ignatianum,' School of Philosophy and Education, 1999).

5 In 1661 John II Casimir Vasa granted the royal privilege to another university run by the Jesuits, further to the east from Vilnius. This too adhered to the structure of the Roman College with the division into only the two disciplinary areas of philosophy and theology. The university was established in the city of Lviv (Leopolis), which is now part of Ukraine, but between 
least at the outset, the spirit of the school was that of training the students for religious life. The Vilnius academy rapidly became the most authoritative centre of the Balkan region and the only Jesuit institution to include in its curriculum the teaching of German, Polish and Ruthenian. The scope of the teaching was reflected in the well-furnished library of the university, which also had its own thriving print shop.

The last of this trio of universities, the Akademia Zamojska, was established in 1595, conceived, designed and funded by one of the most influential and charismatic political figures of Polish history, the Chancellor Jan Zamoyski. However, long before the foundation of these three important institutions the University of Kraków had already been in existence since 1364. Initially set up as a secondary branch of the University of Prague, during the Renaissance period the Jagiellonian University - which up to the nineteenth century was actually called the Academy of Kraków - is still one of the most illustrious centres of higher education in central-eastern Europe. ${ }^{6}$ Like Vilnius, this university was a distinctly Catholic institution, financed directly by the church and with the city's bishop appointed as its rector. Teaching activities were guided by the curia, which was intransigent even, at times, to the point of punishing the masters who failed to abide by its dictates. ${ }^{7}$

1434 and 1772 was in the Ruthenian Voivodeship of the Kingdom of Poland. One of the oldest educational institutions of these eastern regions, before becoming a prestigious Ukrainian academy it was under Austrian, Polish and Soviet administration.

6 Another eminent Polish institution, the University of Breslavia, for example, was founded in 1702. The literature on the Jagiellonian University is vast, especially that inspired by the sexcentenary of the University. See Kazimierz Lepszy (ed.), Dzieje Uniwersytetu Jagiellońskiego w latach 1364-1764 [History of the Jagiellonian University in the years 1364-1764] (Kraków: Państ. Wydaw. Naukowe, 1964); see also Janusz J. Tomiak, "The University of Cracow in the period of its greatness," Polish Review (New York) 16 (1971), no. 2: 25-44; no. 3: 29-44; Gerard Labuda, Rola $i$ zadania uniwersytetów $w$ nowoczesnej organizacji nauki [The role and functions of universities in the modern organisation of science] (Poznań: UAM, 1962); Zofia Skubała-Tokarska, Zbigniew Tokarski, Uniwersytety $w$ Polsce [Universities in Poland] (Warsaw: Wiedza Powszechna, 1972); Lubor Jilek, Historical Compendium of European Universities (Geneva: CRE, 1984); various data here and in the text are taken from Hilde de RidderSymoens (ed.), Universities in Early Modern Europe (1500-180o), in W. Rüegg (general ed.) A History of the University in Europe (Cambridge: Cambridge University Press, 1996), II, 80-89. The most recent study is definitely that by Paul W. Knoll, "A pearl of powerful learning": The University of Cracow in the fifteenth century (Leiden-Boston: Brill, 2016).

7 An eloquent example of the inflexibility of the university and the interference of the Catholic Church in its activities was the discontinuance of the salaries of the philosophy professors Jan z Trzciany, Wojciech Nowopoczyk and Symon Marycjusz for the entire academic year 1548 . This episode is described in Danuta Quirini-Popławska, "Attempts to modernize the Curriculum at Krakow," in Gregorio Piaia and Marco Forlivesi (eds.), Innovazione filosofica e università tra Cinquecento e primo Novecento - Philosophical Innovation and the University from the 
As in the rest of Europe, in the regions of the Commonwealth the universities naturally played a decisive role in the Protestant-Catholic chessboard of the period between the Reformation and the Council of Trent. The Albertina was the Protestant alternative to the Jagiellonian, while Vilnius was a countermove made at the height of the Counter-reformation located in the Lithuanian territories where most of the students of the Albertina came from. ${ }^{8}$ Alongside the universities there were also other secondary education institutes such as the gymnasia of Danzig and Torun, joined after the turn of the century by the school of Leszno and the Gymnasium Bonarum Artium in Raków, also known as the Akademia Rakowska. At the beginning of the sixteenth century a sizeable Protestant community arrived in Leszno, consisting of members of the Moravian Church (Unity of the Brethren) and other outlaws from Silesia. They transformed the small town into a cultural and editorial centre, and the gymnasium founded in the following century became famous and attracted eminent humanists including the Czech theologian Jan Amos Komenský (John Amos Comenius, 1592-1670). Flourishing at around the same time (1602-1638) was the Racovian Academy founded by the Polish Brethren, a nontrinitarian Protestant group also known as Socinians after their leading exponent Faust Socyn (Fausto Sozzini, 1579-1604), an Italian theologian transplanted to Poland. Like the previous gymnasia, the Racovian Academy too never became a university, despite being one of the most renowned educational institutions in the country, numbering among its staff the philosopher and theologian Johannes Crell

16th century to the early 2oth (Padua: Cleup, 2011), 31-49, 35-37. More generally, see also Henryk Barycz, Historja Uniwersytetu Jagiellońskiego w epoce Humanizmu [History of the Jagiellonian University in the Humanist era] (Kraków: Drukarnia Uniwersytetu Jagiellońskiego, 1935); and Lech Szczucki, "Aspekty myśli polskiej XVI wieku," [Aspects of Polish thought in the sixteenth century], in Lech Szczucki (ed.), Filozofia i mysl spoleczna XVI wieku [Philosophy and social thought in the sixteenth century] (Warsaw: Polska Akademia Nauk, Instytut Filozofii i Socjologii, 1978), 9-29. Among the most recent contributions, see Janusz Sondel, Zawsze wierny: Uniwersytet Jagielloński a Kościót rzymskokatolicki [Always loyal: the Jagiellonian University and the Roman Catholic Church] (Kraków: Wydawnictwo Uniwersytetu Jagiellońskiego, 2006). This work focuses on the history of the university, concentrating on its role in the battle against Reformation ideas and in the Christianisation of Poland-Lithuania.

8 There were also numerous pre-university schools in which teaching was concentrated on the study of Greek and Latin while championing either Catholicism or Protestantism. Among the most illustrious on the Catholic side was the Lubranscianum academy, founded by 1519 in Poznań, while the gymnasium of Pińczów gravitated in the orbit of French Calvinism. See Józef Nowacki, "Akademia Lubrańskiego," in Jacek Wiesiołowski (ed.), Jan Lubrański i jego dzieto [Jan Lubrański and his work] (Poznań: Wydawnictwo Miejskie, 1999), 152-180, and Stanisław Kot, "Pierwsza szkoła protestancka w Polsce. Z historii wpływów francuskich na kulturę polską," [The first Protestant school in Poland. On the history of French influences on Polish culture], Reformacja w Polsce [The Reformation in Poland] 1 (1921), 15-39. See also Tworek, Education, 367-368, 372-374. 
(Johannes Crellius), and among its students the astronomer and historian Stanisław Lubieniecki (1623-1675).

The gymnasia and the universities were seen as crucial by Catholics and Protestants alike, since they were like nurseries for fostering growth in the true faith and religious doctrines could be disseminated from the lecterns along with knowledge. However, within this dynamic and variegated panorama, the latest of the three universities, the Akademia Zamojska, appears to be a complete anomaly, not being yoked to either creed.

The bull issued by Pope Clement viII on 29 October 1594 sanctioned its status as a university, and it opened its doors on 15 March of the following year. ${ }^{9}$ Just five years earlier, in 1589, the future pope, at the time Cardinal Ippolito Aldobrandini, had been sent to Poland on a delicate mission by the Holy See, accompanied by his nephew Cinzio. He was to attempt to make peace between Sigismund III Vasa and Maximilian III, Archduke of Austria who had been fighting for the crown of the Polish-Lithuanian Commonwealth since the death of King Stephen Báthory in 1586. When the cardinal arrived in Kraków on 27 July 1588, Maximilian III had been a prisoner of the Swedish king for several months, and it was here that the future pope first met Jan Zamoyski, a staunch supporter of Sigismund III Vasa. During the negotiations for the liberation of the prisoner, the cardinal also went to Prague to speak to the Holy Roman Emperor, Rudolf II. $^{10}$ In the course of these missions he stayed briefly in the city of Zamość, which was at the time a huge and bustling building site, but where an excellent school was already in operation. This college was the nucleus from which Zamoyski aimed to develop the university, and he was assisted at the time by one of the most outstanding poets of the Polish Renaissance, Sebastian Fabian Klonowic $\left(1545^{-1602}\right)$. We do not know whether the presence of this humanist in the school had an impact on the future Pope's consideration of the institution, nor whether the contacts between the two went beyond the official visit. It is nevertheless indisputable that

$9 \quad$ For the papal bull, refer to the manuscript BN воZ 1591 (33.5 X21 cm, $200 \mathrm{ff}$.) entitled Leges sive privilegium vetus Academiae Zamoscensis and conserved in the National Library of Warsaw. The royal privilege was instead not ratified by Sigismund III until 1601, confirming the deed of foundation which was printed in the academy's print shop in 1600 . Further information in paragraph 4 below.

10 There is a manuscript record of this episode drawn up by Giovanni Pietro Maffei entitled Polonica legatio cardinalis Aldobrandini, a copy of which is conserved in the Civica Biblioteca - Archivi Storici "Angelo Mai” of Bergamo. In general, see Ludwig von Pastor, $\mathrm{Ge}$ schichte der Papste seit Ausgang des Mittelalters (Freiburg: Herder \& Co., 1894-1933), vol. 23-24; see also the entry by Agostino Borromeo in Dizionario Biografico degli Italiani, 26 (Rome: Istituto della Enciclopedia italiana, 1982), 259-282 and John Norman Davidson Kelly (ed.), The Oxford Dictionary of Popes (Oxford-New York: Oxford University Press, 1986), $275^{-276 .}$ 
Aldobrandini's impression of the encounters he made at Zamość was positive and his favourable opinion persisted over time. The reputation enjoyed by the nascent university within the Catholic Church is revealed by the fact that the Aldobrandini coat of arms, consisting of a Jacob's ladder surrounded by six stars, was added to the crest of the academy to create a new image.

Nevertheless, once all the authorisations had been obtained, the recruitment of the teachers, who were summoned from all over Europe, was not guided by doctrinal persuasions. Even more significant is the fact that the academy's curriculum of disciplines, traditionally broken down into arts, law and medicine, did not include theology. This was introduced only much later, in 1648, authorised by Pope Innocent $x$.

An understanding of the cultural approach pursued by the academy in the early decades of its activity has to start from the ambitions and interests of its founder Zamoyski, who was able to command powers which were in some ways greater than those of the royal house itself. The numerous roles he held at the Polish court were indicative of his influence in both domestic and international policy: from royal secretary to chancellor and finally Grand Hetman, that is the supreme military commander. However, political commitments and military campaigns did not prevent him from cultivating extensive cultural interests and creating his own city in Renaissance architectural style, Zamość, where he established the new academy between the newly-built walls. Affectionately dubbed 'my dear daughter,'11 the academy was undoubtedly his creature, and although the numerous biographies describe Zamoyski as sympathetic towards Protestant and Calvinist ideas, at least in his youth, he was never tainted by the shadow of heresy. On the contrary, his letters and meetings testify to the fact that the chancellor maintained constant and cordial relations with the Holy See and with the papal legates. His influence on the academy extends in particular to the first thirty years of the school's activity, from its foundation up to the fire of 1627 in which it was seriously damaged and the typography destroyed. It was in this period that the academy made its name as a lay institution capable of training the Polish nobility, that is the ruling class who were to govern the country. The famous inaugural discourse, which Zamoyski made on 3 March 1595, summoned the Poles ('Odezwę do Polaków'), emphasising that the school was intended as an instrument to strengthen the Polish state. ${ }^{12}$ Indeed, if contemporaries are now struck in particular by the

\footnotetext{
11 In Polish 'córka moja droga.'

12 In a letter dated 12 March 1593, addressed to his trusted assistant Szymon Szymonowic, Jan Zamoyski had already defined the academy as a 'civilian school' intended to magnify the glory of God and of the Confederation; this letter is transcribed in Stanisław Łempicki,
} 
religious tolerance which made the Commonwealth, according to a famous definition, 'a state without stakes'13 the State administration too featured certain exceptional elements which were matched in Zamość at educational and cultural level by equally extraordinary programmes.

It is not surprising that one of the three universities founded in the second half of the sixteenth century in the Polish-Lithuanian Commonwealth was a schola civilis. Sixteenth-century Poland was the largest European state to have adopted a mixed form of government which combined the concept of hierarchy with that of representation. It was organised in a federal system of regional parliaments with assemblies which elected their representatives from among the nobility. These representatives then served in the national parliament, the Sejm. The Sejm had broad powers, as indicated by the motto 'Nic o nas bez nas' (Nothing about us without us), which meant that the king could not issue new laws without the consent and approval of the nobility. This principle was enshrined in the title of the original Latin act Nihil novi nisi commune consensus (Nothing new without common consent) endorsed at Radom on 14 June $1505 \cdot{ }^{14}$

The constitutional system went through several transformations, and was definitively codified only after the death of the last representative of the Jagiellon dynasty, Sigismund II Augustus in $1572 .{ }^{15}$ Starting in that year the monarchy

Działalność Jana Zamoyskiego na polu szkolnictwa, 1573-1605 [The activity of John Zamoyski in the field of schooling 1573-1605] (Kraków: Książn. polska w Warszawie, 1922, 140).

13 The expression is taken from the title of Janusz Tazbir's classic study: A State without Stakes. Polish Religious Toleration in the Sixteenth and Seventeenth Centuries (New YorkWarsaw, The Kościuszko Foundation - Państwowy Instytut Wydawniczy 1973). Also interesting is the recent contribution to this topic made by Charles Keenan, "Polish Religious Toleration and Its Opponents: The Catholic Church and the Warsaw Confederation of 1573," in Danilo Facca, Valentina Lepri (eds.), Polish Culture in the Renaissance. Studies in the Arts, Humanism and Political Thought (Florence: Firenze University Press, 2013), $37-52$. More generally, for a broad overview of early modern Poland up to the third partition (1795), see the first volume of the classic study by Norman Davies, God's Playground. A History of Poland (New York, Columbia University Press, 2005 [first ed. 1979]).

14 Robert Frost, The Oxford History of Poland-Lithuania, Volume I: The Making of the PolishLithuanian Union, 1385-1569 (Oxford: Oxford University Press, 2015).

15 See Karin Friedrich, "Polish-Lithuanian Political Thought 1450-1700," in Howell A. Lloyd, Glenn Burgess, Simon Hodson (eds.), History of European Political Thought, 1450-1700 (New Haven: Yale University Press, 2007), 409-447; Tomasz Ciesielski, Anna FilipczakKocur (eds.), Rzeczpospolita państwem wielu narodowości i wyznań:XVI-XVIII wiek [The Polish Republic as a multinational and multi-confessional state] (Warsaw: DiG, 2008). 
became truly elective and the power of the king was further restricted by the so-called 'Henrician Articles.' These were named after Henry of Valois, who nevertheless reigned for only a few months since, upon hearing of the death of his brother, he returned to Paris where a more attractive kingdom awaited him. Despite the sudden flight of the king, the articles remained in force, obliging all who succeeded to the Polish throne to regularly convene the Sejm to makes decisions on matters crucial to the life of the country, such as the economy and foreign policy. ${ }^{16}$ The Henrician Articles, and the follow-up agreement called the Pacta Conventa, also enjoined the king to ensure religious tolerance and to adhere to the rules existing prior to his election and to respect the rights of the nobles including that of Liberum Conspiro, namely of rebelling against the sovereign should he infringe one of his promises.

As regards the szlachta, or nobility, ${ }^{17}$ it is interesting to note that, unlike other European countries, no distinction was made between minor aristocrats and the wealthier magnates; irrespective of their estate all enjoyed the same rights, including that of voting in the Sejm. As the philosopher Tommaso Campanella accurately stated in his Aforismi politici: 'All communities are dominated either by one, such as the king in Spain, or by many, as the nobles of Venice, or by all, like the Athenians or the Swiss, or by one and many together as in Poland. ${ }^{18}$

16 For a general overview of the Polish parliamentary system between the 16th and the 17th century, see Edward Opaliński, Kultura polityczna szlachty polskiej w latach 1587-1652: system parlamentarny a spoteczeństwo obywatelskie [The political culture of the lesser Polish nobility in the years 1587-1652: parliamentary system and civil society] (Warsaw: Wydawnictwo Sejmowe, 1995). There is much literature regarding the image of the Polish state in European culture: still pivotal is the classic study by Stanisław Kot, Rzeczpospolita Polska w literaturze politycznej zachodu [The Polish republic in western political literature] (Kraków: nakł. Krakowskiej Spółki Wydawniczej, 1919), a new edition of which was published in 2017 edited by Lech Szczucki and Janusz Tazbir (Warsaw: Oficjna Wydawnicza ASPRA-JR), used for all following textual references. More recent contributions include Karin Friedrich, Barbara M. Pendzich (eds.), Citizenship and Identity in a Multinational Commonwealth. Poland-Lithuania in Context, 1550-1772 (Boston-Leiden: Brill, 2009).

17 See Jan Krzysztof Federowicz, Maria Bogucka, Henry Samsonowicz (eds.), A Republic of Nobles: Studies in Polish History to 1864 (Cambridge: Cambridge University Press, 1982). Norman Davies notes that scholars are not agreed about the origin of the term szlachta, since it is impossible to determine the specific context in which it was first used. Etymologically, it derives from the term slahta which appears in the Old Low German used in the southern regions, from which modern German words such as schlagen (to strike, fight, cleave, breed) and Geschlecht (sex, family, race, species) derive. It would appear, however, to have come into Polish through the Czech slebta signifying nobility; Davies, God's Playground, 161 .

18 Tommaso Campanella, Aforismi politici, 13, edited by Luigi Firpo (Turin: Giappichelli, 1941), 94 . 
The commonwealth was governed by one and many together, and its statute not only established the active participation of different subjects in the res publica, but also included measures such as the principle of unanimous consent, which again was unique in Europe at the time. This concept, known as liberum veto and derived from mediaeval legal doctrine, is a parliamentary instrument alternative to the majority principle, based on the conviction that what concerns all must be discussed and approved by all. ${ }^{19}$ This universal agreement stemmed from the need to govern a state as geographically vast as the Commonwealth since the legislators were convinced that it would allow the different components of the state to work together. Although it represented a sort of safeguard against one part prevailing over another, the liberum veto also allowed the seed of anarchy to grow within the ranks of the aristocratic democracy, leading increasingly over the following century to a paralysis of parliamentary decisions and often to disaster in the case of war. ${ }^{20}$ Thus the political system of this large country covering a broad swathe of central-eastern Europe was an exceptional case, arousing the interest of thinkers of different persuasions and disciplines who enthusiastically described the country's history and institutional development. Many of their accounts circulated in printed editions of miscellaneous collections, such as the Corpus Polonicae Historiae published in Basle in 1582, which brought together descriptions of the Polish political system by both ancients and moderns, including the opinions of Enea Silvio Piccolomini (Pope Pius II), and Martin Cromer. This book circulated widely at the end of the century, and smaller editions containing the thoughts of just one of the authors were also produced. It completed an already significant literature on the subject, which also included the reflections of a Jesuit who had frequented this region at length: Antonio Possevino. ${ }^{21}$

19 A classic study of the history of the liberum veto is Władysław Konopczyński, Liberum veto. Studium historyczno-porównawcze [Liberum veto. A historic-comparive study] (Kraków: Krakowska Druk. Nakładowa, 1918). Among the more recent and most interesting is Benedict Wagner-Rundell, Common Wealth, Common Good: The Politics of Virtue in Early Modern Poland (Oxford: Oxford University Press, 2015). For a reconstruction of the work of Władysław Konopczyński and the historians' debate on the privileges of the szlachta in the Early Modern period, see the introduction.

20 Zbigniew Ogonowski, "Nad pismami A. M. Fredry w obronie liberum veto," [On the writings of A. M. Fredro in defence of the liberum veto], in Filozofia polityczna w Polsce XVII wieku i tradycje demokracji europejskiej [Political philosophy in Poland in the 17th century and the traditions of European democracy] (Warsaw: Polska Akademia Nauk, Instytut Filozofii i Socjologii, 1992), 9-57:25.

21 Possevino was engaged in founding, strengthening and monitoring the various colleges and seminaries established by the Society of Jesus within the Commonwealth. Information about these missions can be found in his letters, in the Commentario di Transilvania, 
Among the leading political writers of the Counter-Reformation period there were also some who criticised the elective monarchy, like Jean Bodin in his Six livres de la Republique (1576), followed eighty years later by Herman Conring, who addressed the subject in his De iustitia armorum Suecorum in Polonos (1655), discerning the seeds of civil violence and social injustice in the privileges of the szlachta. ${ }^{22}$ On the other hand, the right to conspire against the sovereign endorsed by the Polish constitution was greatly admired in $\mathrm{Hu}-$ guenot circles, which were acutely concerned with the legitimacy of the power of the people against the king. An excellent example of this is one of the most famous works adopting a critical stance towards absolute monarchy: the Vindiciae contra tyrannos (1579). This short work published anonymously in Basle identified only two ideal models of institutional system in Europe: the PolishLithuanian Commonwealth and the Republic of Venice. Finally, Giovanni Botero should also be briefly mentioned, since his exhaustive historical, geographical and social reconstruction of the Relazioni Universali also included the Polish constitutional system. In the fifth part of this work, considering the economic resources of the country in detail, he also defines its constitution as more republican than monarchist, praising not so much the mixed system in itself but the skill of the sovereign who must be capable of administering command. ${ }^{23}$

composed in 1584 but not printed until the 2oth century, and in the Moscovia, printed in Vilnius in 1586. The introduction to his Bibliotheca selecta qua agitur de ratione studiorum (Rome: Tipografia Vaticana, 1593), contains information about his journeys to central-eastern Europe. The dedicatees are Pope Clement VIII and Sigismund III Vasa, King of Poland and Grand Duke of Lithuania. The list of Possevino's printed works is in Carlos Sommervogel, Bibliothèque de la Compagnie de Jésus, vi (Bruxelles-Parigi: Oscar Schepens-Alphonse Picard, 1895), coll. 1061-1093.

22 Hermann Conring, Cyriaci Thrasymachi De justitia armorum Svecicorum in Polonos, perque ea liberata a magno periculo Germania ad Andream Nicanorem epistola, in fine accessit panegyricus autoris ... (Lipsiae: Bauer, 1655). See Kot, Rzeczpospolita Polska, 107-108; Davies, God's Playground, 277-278; Mieczysław B. Biskupski and James S. Pula (eds.), Polish Democratic Thought from the Renaissance to the Great Emigration: Essays and Documents (New York: Columbia University Press, East European Monographs, 1990), 41.

23 The first part of Delle relationi universali was published in Rome by Giorgio Ferrari in 1591. See also Maria Luisa Doglio, "Principe, nazione, regni nelle Relazioni universali del Botero: il modello della Polonia," in Vittore Branca and Sante Graciotti (eds.), Cultura e Nazione in Italia e in Polonia dal Rinascimento all'Illuminismo (Florence: Olschki, 1986), 299-316. More generally on the image of Poland in Italian Renaissance culture, see again Kot, Rzeczpospolita Polska, ch. "Opinie Włochów o Polsce," [The Italians' opinions of Poland] and Pietro Marchesani, "La Polonia nella storiografia Italiana del XVI e XVII secolo: i clichés ideologici e la loro evoluzione," Europa orientalis, 5 (1986), 203-231. 
In this ramified political scenario, the focus of analysis of a significant body of coeval literature, the Akademia Zamojska was seen as the benchmark institution for the training of the future ruling class. The schola civilis established in Zamość was the first in Poland designed with this precise intention and the only one structured in this way in the history of the country. Its primary aim was to provide the scions of the nobility with the knowledge necessary for the exercise of power, since after receiving the appropriate education they were destined to fill roles of great responsibility for the prosperity of the Commonwealth.

\section{The School and the City}

The attention of the academy was addressed to a part of the population which, at the time, represented about 9-10\% of the total. ${ }^{24}$ The historic roots of the szlachta date back to the early Middle Ages, but continue to be shadowy in some respects, since the acquisition of its privileges are documented only from the thirteenth century. ${ }^{25}$ As a social elite made up of landowners, the nobility was able to obtain various concessions, especially between 1370 and 1386 , that is in the period of passage between the Piast, Anjou and Jagiellon dynasties. Among the prerogatives they acquired was the Privilege of Koszyce, drawn up in 1374 with Ludwik Węgierski (Louis I of Hungary, 1326-1382), King of Poland from 1370, who freed the szlachta from various obligations towards the sovereign and from onerous taxes. ${ }^{26}$

24 According to the calculations of Norman Davies, the percentage of the total population belonging to the nobility was around $7 \%$ in 1569 , reaching peaks of $9 \%$ in the second half of the 17 th century, see "Szlachta: The Nobleman's Paradise," in God's Playground, 156-196: 170-177. More recently, other hypotheses have proposed higher and more stable percentages corresponding to $10 \%$, see, for example, Mark Brzezinski, "Early Polish Constitutional History," in Id., The Struggle for Constitutionalism in Poland (New York: St. Martin's Press, 1997), 34. The percentages could be different depending on regional variations, especially as regards the situation in the southern regions.

25 Apropos this, Davies records that most of the Polish and Lithuanian nobility claimed to belong to the 'szlachta odwieczna,' that is 'the immemorial nobility,' demonstrating that they had no knowledge of their own origins. See Davies, God's Playground, 161.

26 See Wacław Uruszczak, Historia państwa i prawa polskiego, 966-1795 [History of the Polish State and law 966-1795] (Warsaw: Wolters Kluwer, 2010) and, more in general, Anna Sucheni-Grabowska, Wolność i prawo $w$ staropolskiej koncepcji państwa [Liberty and law in the ancient Polish conception of state] (Warsaw: Muzeum Historii Polski, 20og). Also important are the studies of Andrzej Wyczański, including Polska Rzecza Pospolita szlachecka, 1454-1764 [Poland as the res publica of the nobles, 1454-1764] (Warsaw: 
This somewhat heterogeneous nobility needed to receive a preparation suitable for the delicate office it would be called upon to fill. The students had to have a good knowledge of law, be able to employ the tools of eloquence adroitly, be familiar with ancient history and also with the social and political situation in their own country and others. It was an ambitious educational project in which the founder invested considerable time and major financial resources. From the very start the academy was organised around a precise programme of studies taught by a brilliant group of masters from both Poland Kraków in particular - and all the rest of Europe. To optimise the teaching, the masters had a library at their disposal, which was constantly updated with printed books and codices depending on the educational requirements. There was also a publishing house, which played a particular role in the academy. On the one hand, the printing works casts light on the collaboration between the masters in the preparation of the texts, and also on their research interests; on the other, it also clarifies the aims of their work as teachers since most of the texts were used by them. Unlike many other universities in central-eastern Europe, the academy planned its own editions and managed a printing works where the books were primarily destined to the teaching activities, integrating the already rich collection of the library. Within the Commonwealth, only the Jesuit university in Vilnius had similar autonomy. However, the most distinctive aspect is that in Zamość many of the teachers made an active contribution to the editorial production. Naturally their spheres of competence varied, since they were experts on law, philosophers, physicians or intellectuals, but in the print shop they worked side by side, and sometimes as a team, playing different roles on each occasion. For one book one of the masters might be the editor, working alongside a colleague preparing the translation of the text, and in the following project he might be responsible for the preface, with other colleagues assisting him in the editing, and so forth. There are numerous traces of this joint activity in the dedicatory letters of the printed books, in the manuscripts archive and among the letters exchanged between the academics, which can shed light on aspects of the cultural life of the school hitherto little explored.

Although the academy occupied a precise location in the city of Zamość, and the period in which it was operative, from its foundation in 1595 to 1784 when it was downgraded to a mere lyceum, ${ }^{27}$ is also clearly defined, the actual

Państwowe Wydawnictwo Naukowe, 1965), and Szlachta polska XVI wieku [The Polish nobility in the 16th century] (Warsaw: Wydawnictwo Naukowe PWN, 2001).

27 When this region came under the control of the Habsburg Imperial Empire following the partition of Poland. 
sites of learning - the classrooms, the library and the print shop - still have their shady corners. Even its heyday, coinciding with the first thirty years of its life, when the school was driven by Zamoyski's enthusiasm and resources, conceals gems that can offer fascinating evidence of the teaching activities in a university of the early modern age.

This is not to say that the history of the school has been neglected by the academic world; on the contrary, much careful research has been produced, by Polish scholars in particular. However these publications have limited visibility since they are accessible only to those familiar with Slavic languages. This is a serious omission, especially since the history of early modern universities and academies is a field that has recently attracted new interest from historians of scientific and philosophical thought and literary historians. This reawakened interest is enhanced by the use of digital platforms and data organisation programmes, which are crucial for organising the large quantity of information and documents and for a more efficient visualisation of the network of contacts and relations underpinning Renaissance academic life. As well as new technologies, historiographical approaches such as prosopography can contribute to fuel this strand of research and keep it alive. The collection of information for the reconstruction of individual biographies sheds light on the academic community as a whole, illustrating the work of the masters both independently and in collaboration. In addition, it also provides a useful tool, almost a compass, that can help trace the circulation of ideas and editorial products outside the academy.

Study of the pioneering and experimental universities of the early modern age, such as that of Zamość, brings to the fore strong links between the cultural sphere and the political and social realities of the time. Established as institutions for the divulgation of knowledge, they were often of a non-public and non-territorial character. They were schools for educating the future ruling class while existing outside the political systems of the host countries. The professors were experts originating from different countries who often proposed teaching programmes encompassing numerous cultures and viewpoints. In a word, the leading universities of the early modern age had a truly European scope, which explains the fascination they still exert today. Nevertheless, despite the exceptional nature of the experiment carried out in this Polish city, it has had little attention outside Poland, and Zamość is scarcely considered in the international context and in the humanist network in which it historically evolved.

Notwithstanding the wars and invasions suffered by Poland over the centuries, a conspicuous part of the documents and publications of the academy has miraculously survived. The archive still contains precious documentation 
of the intellectual life of the time that can be only partially presented here but which, in general, open up further paths of research.

The school was built over an eight-year period in the centre of Zamość which, like the academy, reflected the magnificent project conceived by its most illustrious citizen, Jan Zamoyski. While in the service of Stephen Báthory, the chancellor had accumulated a huge amount of land, in total comparable to the surface area of the Republic of Venice. He chose from among these boundless landholdings a region in the south-east of Poland, in the Lublin Voivodeship (Województwo Lubelskie), comprising six towns and 149 villages. This was where Zamoyski had been born, in the village of Skokówka, and where the old family castle had stood.

Like Kraków and Vilnius, the city of Zamość was designed with a dual economic and cultural mission. The city was situated in a strategic trading position halfway between Lublin and Lwów, and Zamoyski intended it to become a developed and competitive mercantile hub. In the following decades it hosted numerous fairs and became an important junction for the transit of goods of different kinds. However, in the eyes of his contemporaries the new city was not seen only as a business centre, but also as a place conceived to enhance culture, where people could study and directly experience art. In the construction of the buildings and fortifications and in the urban decor the styles and canons of sixteenth-century architecture were fused with meticulous planning solutions.

The person commissioned by Zamoyski to make Zamość into a gem of Renaissance art north of the Alps was the Italian architect Bernardo Morando, who was born either in Venice or Padua and arrived in the Commonwealth around $1570 .{ }^{28} \mathrm{He}$ worked here on several minor projects until he made a visit to Lwów where, in July 1578 he signed the first of a series of contracts that bound him indissolubly to Zamoyski. The collaboration between the architect and the magnate continued up to the end of Morando's life in the very city he had created. Unfortunately all that has come down to us is a handful of documents concerning him and five autograph letters, all addressed to his illustrious commissioner and relating to the construction works, although they do not contain drawings or diagrams that enable the entire enterprise to be precisely reconstructed.

His main source of inspiration came from the new military cities that were built around the middle of the century, featuring polygonal city walls and a

28 Maria Lewicka, Bernardo Morando (Warsaw: Wydawnicza Instytutu Urbanistyki i Architektury, 1952), 143. PSB, 21, 1976, Jerzy Kowalczyk, 693-694. See also the entry by Gerardo Doti in the Dizionario Biografico degli Italiani, 76, 2012, 481-486 and the related bibliography. 
regular road network. Morando revealed an excellent knowledge of engineering and military architecture, which must have been at least partially the result of his friendship with the architect and town planner Michele Sanmicheli whom he probably met in the 1540 in Venice. ${ }^{29}$ In the organisation of the actual buildings, the size of which was related to their function in city life, he drew guidance from the Seven Books on Architecture by the Bologna-born Sebastiano Serlio (1475-c. 1544). There are numerous indications that architect and commissioner worked together on the design of the city, including the letters they exchanged. Striking evidence of their shared interest is the presence in Zamoyski's library of various works on architecture, some of which may have been purchased during his long sojourn in Italy when he actually met Morando. ${ }^{30}$ He also continued to acquire works on the subject after his return home, such as the Venetian 1567 edition of Four Books on Architecture by Pietro Cataneo. ${ }^{31}$ Sometimes these were sent as gifts by architects in search of new commissions, as may have been the case of Bonaiuto Lorini, who sent Zamoyski a copy of his newly-printed book on fortifications on 15 December 1597 when the city worksites were still in operation. ${ }^{32}$

Based on reconstructions of Morando's general plan, ${ }^{33}$ it appears that the architect arranged the longitudinal roads in such a way as to create different visual corridors (also known as telescopic perspective) culminating in certain

29 Jerzy Kowalczyk, "Morando e Zamoyski. La collaborazione tra un architetto veneto e un mecenate polacco nella creazione della città ideale," in Mieczysław Brahmer (ed.), Italia, Venezia e Polonia, tra Umanesimo e Rinascimento (Wrocław-Warsaw-Kraków: Wydawnictwo Połskiej Akademii Nauk, 1967), 335-351: 337; more generally see Id., Zamość, città ideale in Polonia. Il fondatore Jan Zamoyski e l'architetto Bernardo Morando (Wroclaw: Ossolineum, 1986); Zygmunt Wazbinski, "Bernardo Morando e il suo contributo alla difesa dei confini orientali della Polonia," in Carlo Cresti, Amelio Fara, Daniela Lamberini (eds.), Architettura militare nell'Europa del XVI secolo. Atti del Convegno di studi (Siena: Periccioli, 1988), 271-278; Marino Viganò (ed.), Architetti e ingegneri militari italiani all'estero dal XV al XVIII secolo (Livorno: Sillabe, 1994), 14, 19, 21 nos. 21, 27; 28, no. 8.

30 See PSB, 21, 693 .

31 The princeps dates to 1554: I quattro primi libri di architettura (Vinegia: in casa de' figliuoli di Aldo).

32 This book Delle fortificazioni was printed in Venice in 1596. Both the copy itself and the accompanying letter are now conserved in the Narodowa library (manuscript XVI, f. 1413). On this episode see Stanisław Łempicki, Renesans i humanizm w Polsce [Renaissance and Humanism in Poland] (Warsaw: Czytelnik, 1951), 361-383. More generally, see Jerzy Kowalczyk, Kultura i ideologia Jana Zamoyskiego [The culture and ideology of Jan Zamoyski] (Warsaw: Instytut Sztuki Polskiej Akademii Nauk, 2005).

33 See Wojciech Kalinowski and Teresa Zarębska, "Zamość, città ideale del Rinascimento e sua realizzazione," in Annalisa Guarducci (ed.), Investimenti e civiltà urbana, secoli XIII$X V I I I$, proceedings of the 'Nona settimana di studi' (Firenze: Le Monnier, 1989), 17-22. 
buildings placed at the western perimeter of the city. In this way, the streets framed Zamoyski's palace, the garden, the arsenal and the residence of the chancellor's consort, which were all in the most westerly part inside the fortified walls. The city was cut in two in a north-south direction by the main axis, in the very centre of which was the main porticoed square with the town hall. Two other streets ran parallel to the main street, the one on the eastern side leading to the church, with the collegiate church and the hospital close to it, and that on the western side to the academy complex, comprising the residences for the students and the masters.

Works officially began in 1580 and were carried out in three phases. During the first phase, up to 1585 , Zamoyski's own residence and the arsenal were completed. In the second phase, which continued up to 1594, the year in which the creation of the academy was authorised by papal bull, the defensive ramparts were built and construction began on the church. The last phase of construction focused on the belltower of the church, the university buildings and the adjacent printing works, although the construction of the academy was not completed until 1598, that is three years after the official launch of the teaching activities. ${ }^{34}$ Looking at the city from above, within the asymmetrical polygon of the walls, the collegiate church and the academy stand opposite the Zamoyski castle, the former occupying the north-western quadrant and the school the south-western quadrant.

Just as the plan of the city drew inspiration from different architectural models, the organisation of the academy also took cues from various foreign institutions. The influence of other universities is evident even in the arrangement of the buildings, with the student residences divided into 'nations', as was the practice in Italy, especially in Bologna, and had also been adopted in Paris. ${ }^{35} \mathrm{In}$ Zamość there were five different groupings based on geographical provenance: Polish, Lithuanian, Russian, Prussian-Livonian and the last which brought

34 Except for the church, which can still be admired today as it was conceived and constructed by Morando, all the other buildings have been either demolished or extensively remodelled.

35 On the organisation of the dormitories and lodgings of the students and teachers of the academy see Henryk Gmiterek, "Bursa Starnigela przy Akademii Zamojskiej," [Starnigel's student residence at the Akademia Zamojska], Rocznik Lubelski [Lublin Annual] 19 (1976): 21-38. 
together all the other foreign students in the academy, originating from Italy, England, Germany, Greece, Armenia etc.

While this grouping of the students into nations is quite clearly based on the Italian example, the models which guided the teachers in their educational approaches and the choice of textual materials are obviously harder to pin down. The picture emerging from the research is quite varied, and for this reason too the academy has at times been seen as a sui generis institution within Europe, moulded by eccentric decisions and the founder's intentions. While it is true that the conception of the school featured certain exceptional aspects, this can also be said of a good number of other universities in the early modern age. In other words, its multigenetic and multiform nature is comparable to that of other schools, especially those located in borderlands, geographically more exposed and hence more open to cross-contamination between different educational models. The best approach for pointing up these distinctions is to first clarify which of the educational models in use at the end of the sixteenth century the academy was inspired by.

To distinguish universities from gymnasia, lyceums and academies of various kinds, in general the legitimisation conferred since the Middle Ages by the Empire and the Church on some schools rather than others can be used as a benchmark. University status was acquired by the granting of this privilege, as mentioned at the start of this chapter with reference to the Albertina. Based on these criteria, the academy established by Zamoyski can undoubtedly be classified as a university, since it obtained all the required authorisations a year before the official opening, in 1594. Nevertheless, at the end of the sixteenth century the distinction between school and university cannot be categorically linked to possession of the privilege, since this would assume unanimous recognition by the community involved of the authority of king or pope. In the case of one state being conquered by another or, even more importantly, when the Protestant Church emerged alongside the Catholic Church, then the criterion of legitimisation also has to be reconsidered in the light of the social and political context in which the new university is established. ${ }^{36}$

The distinctions are easier to make apropos the internal organisation of the schools, since the sixteenth-century universities conformed to one of two main systems, known respectively as the Paris model and the Bologna model. In the Paris model the university is made up of both masters and students, but is dominated by the teaching body since the students are mere suppositi, that is members of the university without any decision-making power. Instead, in

$3^{6}$ These pages are fundamentally based on Wilhelm Frijhoff, "Pattern," Chapter 2, in Universities in Early Modern Europe (1500-1800), 43-105. 
the Bologna model, which is actually older, the university is made up of the students and they select and summon illustrious masters to train them in the various disciplines. According to the oldest chronicles, the University of Bologna did not have any permanent premises until the middle of the sixteenth century, and the teachers gave their lectures in rooms rented from the City Council or in their own homes. Known in the Middle Ages as Studium, this system developed as a free and secular association of students directly in charge of the recruitment and emoluments of their teachers. In the same spirit of self-government, the students organised themselves into colleges so that those of the same nationality could help each other. These were the same nationes that we have already mentioned in relation to Zamość, which initially divided the students only into citramontani and ultramontani, relating to regions respectively this side and the other side of the Alps. In other words, the Bologna model is a universitas scholarum growing from the grassroots and the spontaneous aggregation of masters and pupils, whereas the Paris model is a universitas magistrorum created by foundation and connected with the Church and the sovereign authority that endorses its creation.

The Paris model was the most common in Europe, even though it was not strictly applied and was re-elaborated in three different versions. There were, for instance, centralised universities organised in a system of faculties offering specialised preparation in various disciplines. Then there were universities which, despite dividing the disciplines into faculties, offered less specialised teaching and were also distinguished by the collegial life of masters and students. The last version was something between the other two, offering a degree of specialisation in certain fields while also having a collegial system. In general these were smaller universities, which emerged more commonly in outlying areas of Europe, such as Scotland, Ireland and the regions of eastern Europe. ${ }^{37}$

By and large, the Akademia Zamojska falls into this last group, but again one has to be cautious about making generic comparisons. As the following chapter will show in detail, far from being marginal or isolated, the founder of the school and several of its most brilliant masters had attended some of the most illustrious academic institutions of the time, bringing home with them cultural approaches, teaching methods and books. ${ }^{38}$ The aim here is simply to focus the general scholastic organisation of the academy, and on this point scholars are agreed that Zamoyski's visit to the Schola Argentoratensis, the

37 Ibid., 64-70.

38 Henryk Barycz, "Studia zagraniczne Jana Zamoyskiego," [Jan Zamoyski's studies abroad], in Jerzy Kowalczyk (ed.), Czterysta lat Zamościa [Four hundred years of Zamość] (Wrocław: Zakład Narodowy im. Ossolińskich, 1983), 229-231. 
dynamic Protestant gymnasium in Strasbourg, had a preponderant influence. ${ }^{39}$ It was a relatively short visit which, according to recent research, lasted only for a couple of months in 1559, but sufficient nevertheless to leave an impression on the teaching programmes conceived in Zamość thirty years later. ${ }^{40}$

In the second half of the sixteenth century several schools appeared on the European scene which were authentically innovative in organisational terms and were the subject of discussion among teachers and intellectuals. They shared the wish to introduce the liberal arts into the scholastic system, placing them at the hub of the students' education, which was at the time considered inappropriate. ${ }^{41}$ The most successful examples include quasi-university institutions such as the Collegium Trilingue in Louvain, inspired by the teaching of Erasmus of Rotterdam and the above-mentioned Schola Argentoratensis, better known as the Jean Sturm Gymnasium, which was later to develop into the University of Strasbourg.

This school, which opened in 1538, was conceived by Johannes Sturm to educate young people in letters with the aim of developing both their knowledge and their eloquence. ${ }^{42}$ His pedagogic programmes are expounded in various

39 On the influence of Sturm's teaching system on Zamoyski's plans for his academy, see: Łempicki, Działalność Jana Zamoyskiego, 279-292; Izydora Dąmbska, "Filozofia w Akademii Zamojskiej w dobie Renesansu," [Philosophy at the academy of Zamość in the Renaissance], in Lech Szczucki (ed.), Nauczanie filozofii w Polsce $w$ XV-XVIII wieku [The teaching of philosophy in Poland from the 15th to the 18th centuries] (Warsaw: Polska Akademia Nauk. Instytut Filozofii i Socjologii, 1978), 87-114, 87-114: 96-97; Stanisław Kot, "Promieniowanie Strasburga na Polskę w dobie Humanizmu," [The influence of Strasbourg on Poland in the Humanist period], in Henryk Barycz (ed.), Polska ztotego wieku a Europa. Studia i szkice [Poland in the Golden Age and Europe. Studies and essays] (Warsaw: Państwowy Instytut Wydawniczy, 1987), 487-508; Zdzisław Pietrzyk, W kręgu Strasburga. Z peregrynacji mtodzieży z Rzeczypopsolitej polsko-litewskiej w latach 1538-1621 [In the Strasbourg circle. On the peregrinations of young people from the Polish-Lithuanian Republic in the years 1538-1621] (Kraków: Nakł. Biblioteki Jagiellońskiej, 1997).

40 The new hypothesis of dating is made by Marian Chachaj in "Studia zagraniczne Jana Zamoyskiego: fakty, domysły, nieporozumienia," [The foreign studies of Jan Zamoyski: facts, conjectures and doubts], Czasy Nowożytne [Modern Times] 2 (2013): 42-43. Karol Estreicher and Henryk Barycz think differently, indicating the date of arrival as 1557. Estreicher, 32, 1938, 409; Henryk Barycz, "Pod urokiem humanistycznego Paryża," [Under the charm of Humanist Paris], in Id., $Z$ dziejów polskich wędrówek naukowych za granice [On the history of the Poles' study trips abroad] (Wrocław: Zakład Narodowy im. Ossolińskich, 1969), 211-242: 240.

41 See Anthony Grafton, Lisa Jardine, From humanism to the humanities. Education and the liberal arts in fifteenth and sixteenth-century Europe (Cambridge [Mass.]: Harvard University Press, 1986).

42 As clarified in one of his most famous works: 'Propositum a nobis est, sapientum atque eloquentem, fine esse studiorum.' Johannes Sturm, De literarum ludis recte aperiendis liber. 
treatises and systematically in three works. The first two were published in the period in which the gymnasium was being organised -De literarum ludis recte experiendis $\left(1538\right.$, in $\left.4^{\circ}\right)$ and De amissa ratione dicendi $\left(1538\right.$, in $\left.4^{\circ}\right)$ - while the third is the collection of letters entitled Classicae epistolae sive Scholae Argentinienses restitutae published in $1565 .^{43}$ In planning the gymnasium, which was initially a secondary school, Sturm drew inspiration from that of St. Jerome in Liège where he himself had begun his studies, later continuing in Louvain, after which he went to Paris in 1529, where he lectured first on medicine and then on letters. ${ }^{44}$ In France he obtained the support of influential intellectuals and politicians, including the Cardinal Jean du Bellay and the humanist Guillaume Budé, while he acquired great fame through the lectures he held at the Collège de France commenting on the works of Cicero and Rudolph Agricola. When he moved to Strasbourg in December 1536 he was initially employed as a teacher of logic and rhetoric, but the plan for renewal that he proposed to the city council immediately earned him the role of rector, and he continued to run the gymnasium up to 1583 . His system became a shining example for

De la bonne manière d'ouvrir des écoles de Lettres (Strasbourg: Presses Universitaires de Strasbourg, 2007) (Fac-similé et traduction française de l'exemplaire publié en 1538 à Strasbourg chez Vendelin Rihel, et conservé à la BNUS : R 102 304).

43 Jean Rott, "Bibliographie des oeuvres imprimées du recteur strasbourgeois: Jean Sturm (1507-1589)," in Actes du 95 congrès des sociétés savantes (Paris: Bibliothèque nationale, 1975). Of the three works cited only the last is available in a critical edition: Johannes Sturm, Classicae Epistolae sive Scholae Argentinienses restitutae (1565), edited by Jean Rott (Paris: E. Droz; Strasbourg: Fides, 1938).

44 There is a conspicuous bibliography on Sturm and here I mention only some of the more important studies: Charles Schmidt, La Vie et les travaux de Jean Sturm, premier recteur du Gymnase et de l'Académie de Strasbourg (Paris: Librairie Fischbacher, 1855) (anastatic reprint, Nieuwkoop: B. de Graaf, 1970); on his method see Pierre Mesnard, "The Pedagogy of Johann Sturm (1507-1589) and its Evangelical Inspiration," Studies in the Renaissance 13 (1966): 200-219; Jean-François Collange, "Philipp Melanchton et Jean Sturm, humanistes et pédagogues de la Réforme," Revue d'histoire et philosophie religieuses 68 (1988): 5-18 and Barbara S. Tinsley, "Johann Sturm's method for humanistic pedagogy," in Sixteenth Century Journal 20, no. 1 (1989): 23-41; Matthieu Arnold, "Le projet pédagogique de Jean Sturm (1507-1589): originalité et actualité," in Revue d'Histoire et de Philosophie religieuses 87 (2007): 385-413. More generally see Matthieu Arnold (ed.), Johannes Sturm (1507-1589): Rhetor, Pädagoge und Diplomat (Tübingen: Mohr Siebeck, 2009). Finally, Lewis William Spitz, Barbara Sher Tinsley, Johann Sturm on Education: The Reformation and Humanist Learning (St. Louis: Concordia Publishing House, 1995). This book contains English translations of nine of Sturm's treatises: "Advice on What Organization to Give to the Gymnasium in Strasbourg" (1538); "The Correct Opening of Elementary Schools of Letters (1538); On the Lost Art of Speaking" (1538); "Liberally Educated Nobility", for the Werter Brothers (1549); "On the Education of Princes" (1551); “Concerning the English Nobility", for Roger Ascham (1551); "The Lauingen School" (1565); "Classical Letters" (1565); and "Academic Letters" (1569). 
German Protestant schools, and its influence extended to schools in Switzerland, France and even Poland. In addition to the Akademia Zamojska, it also took root in the gymnasium of Torun, which like the Albertina was in the territories of Royal Prussia and was hence open both to Reformation ideas and to a Melancthonian approach to study.

Two aspects in particular of Sturm's scholastic system were also applied in the Akademia Zamojska: the division of the education of the students into two levels and a particular attention to the teaching of rhetoric. In the academy, in line with the humanist's own experience in his school in Liège, the course of studies was broken down into two levels: an initial phase of preparation centred on the liberal arts and the study of Latin and Greek grammar, followed by a second more specialised programme of study.

Sturm's school was divided into nine classes numbered in descending order. In the ninth class the children were taught to understand the shapes of the letters, how to put them together and how to pronounce them, and then in the eighth class they learnt how to read and write and the rudiments of grammar. Grammar was studied in greater depth in the following classes, and supplemented with the study of poetry and eloquence, while the writers considered most appropriate were Cicero and Terence. ${ }^{45}$ From the fifth class Greek grammar was introduced alongside Latin, as well as precepts of rhetoric and style. The benchmark texts here were Aesop and Demosthenes, together with the reading of Cicero's De officiis. Rhetoric was also at the centre of education in the following fourth class, where the students analysed Cicero's Rhetorica ad Herennium and the Partitiones oratoriae. This subject was perfected in the third class, along with dialectics and through the teaching of Aristotle and, again, of Cicero. Space was also devoted to the historians: Demosthenes and Aeschines among the Greeks and Sallust, Caesar and Livy among the Latins. In the second class, the ornatus made way for the aptum and the readings envisaged by the programme were again the Partitiones and Cicero's Orator. The pupils also studied Aristotle's Organon, Platonic philosophy, Euclidean mathematics and law, completing the cycle in the first class where they addressed the reading of the Holy Scriptures. ${ }^{46}$

Sturm first illustrated this proposal in a Memorandum which he presented to the City Council of Strasbourg on 24 February 1538, and shortly afterwards it became the basis for the already-mentioned De literarum ludis recte experiendis, where the number of classes was increased from the original eight to

45 Sturm, De literarum, ff. 13-18. See also Arnold, Le projet pédagogique, 400-401.

46 Sturm, De literarum, ff. 23-24. 
nine. ${ }^{47}$ More generally, the treatise recommends the use of disputationes to enhance learning, as well as a single site for lessons. While for the first classes Sturm considers one teacher sufficient for all subjects, in the top two classes he sees the need for several masters in view of the number and difficulty of the subjects. ${ }^{48}$

Within the study programme the tools of rhetoric were an essential part of the pedagogical system, which explains why the ancient Greek texts on the subject were of the greatest interest to Sturm, who in many cases executed the translation from Greek to Latin himself. Among the most important were the De inventione attributed to Hermogenes and Aristotle's Rhetoric. ${ }^{49}$ Like Melanchthon, he considered dialectic and rhetoric crucial to all intellectual training, and one of the leading lights in this field was Cicero, whose works appear both in the teaching programmes of the gymnasium and in the reflections of the founder. Sturm had dedicated some of the Paris lectures to Cicero, and later printed the Partitionum dialecticarum libri, expanded and re-edited several times, and a commentary on the Tusculanae Disputationes. ${ }^{50}$

In Strasbourg the teaching of rhetoric and dialectic were inextricably bound up with the didactic method. In Zamość too these subjects were given considerable attention, which cannot however be seen as a mere emulation of the Sturm system. The disciplines of the new academy stemmed from numerous

47 The nine classes are also confirmed in the Classicae epistolae; it was a significant number considering that, at the time, there were generally only five, see Arnold, Le projet pédagogique, 396 .

48 Marcel Fournier, Charles Engel, Les statuts et privilèges des Universités françaises depuis leur fondation jusqu'en 1789, Deuxième partie: Seizième siècle, Tome IV: L'Université de Strasbourg et les académies protestantes françaises, 1894 (Paris: L. Larose et Forcel, 18901894), (Amsterdam: Scientia Verlag Aalen, 1970), 18-20.

49 I shall return in greater detail to the relationship between Sturm, the thought of Hermogenes and the teaching of the academy in Chapter 3. On the influence of Hermogenes in the Renaissance see Annabel M. Patterson, Hermogenes and the Renaissance: Seven ideas of style (Princeton: Princeton University Press, 1970). Sturm's translation of the beginning of Aristotle's Rhetoric is exhaustively examined in Alexandra Trachsel, "Johannes Sturm's methods of translations. Examples from the field of rhetoric," in Johannes Sturm (15071589). Rhetor, Pädagoge und Diplomat, 131-146. Trachsel maintains that Sturm's work is similar to that of Ermolao Barbaro, Marc-Antoine Muret, Carlo Sigonio and Jean Strazel, while it differs from the versions of Trebizonda and Pier Vettori.

5o Ioannis Sturmii in partitiones oratorias Ciceronis dialogi duo (Strasbourg: Kraft Müller, 1539). According to the information present in the Universal short title catalogue, after the princeps seven new expanded versions were printed over the 16th century: in 1540, two in 1549 (one published by Blasius Fabricius and the other by him again together with Kraft Müller), in 1559, 1565, 1575 and 1576. Commentarii in M. T. Ciceronis Tusculanam primam. Confecti ex scholis Joannis Sturmii in eandem, nunc primum editi, opera et studio Joannis lobarti Borussi (Argentorati: excussi apud Bernhardum Iobinum, 1575). 
sources of inspiration and, above all, the fundamental education in prudentia civilis.

The deeds of foundation contain information about the internal organisation of the academy, the various regulations governing the work of the teachers and the lesson times. The deeds were drawn up by Zamoyski himself, possibly in liaison with the most influential professor of the academy, Szymon Szymonowic (1558-1629) and other academics; they are dated 5 July 1600 and were approved on 23 September of the following year by Sigismund III Vasa.

The printed versions of these deeds have unfortunately been lost, but we know the contents through a manuscript copy drawn up in the second half of the seventeenth century which, before it too was lost, was published by the historian and theologian Jan Ambroży Wadowski (1839-1907) at the beginning of the twentieth century. ${ }^{51}$ The manuscript described by Wadowski was made up of 133 pages, all numbered except for the first three, and contained various documents concerning the history and life of the academy. At the top of the first page was the shelfmark ' 292 Czarnołuski K. K. Z.', while on the second page the title had been added in a more recent hand: Liber documentorum ex archivis et actis collegiatae et Academiae Zamoscensis excerptorum. ${ }^{52}$

$5^{1} \quad$ Anacephaleosis professorum (see table of abbreviations). The first version in Polish is in Jan Karol Kochanowski, Dzieje Akademii Zamojskiej (1594-1784) [History of the Akademia Zamojska (1594-1784)] (Kraków: Druk W.L. Anczyca i Spółki, 190o), 33-40, subsequently the document was summarised by Łempicki in his Dziatalność Jana Zamoyskiego, Chapters 1-3. See also "Fundacja Akademii Zamojskiej," [Foundation of the Akademia Zamojska], in Ignacy Chrzanowski, Stanisław Kot (eds.), Humanizm i reformacja w Polsce: wybór źródet dla ćwiczeń uniwersyteckich [Humanism and Reformation in Poland: selection of sources for university exercises] (Lwów: Wydaw. Zakładu Narodowego im. Ossolińskich, 1927), 497-503.

$5^{2}$ For a detailed description of the document see Wadowski. Only the sections most pertinent to a reconstruction of the early period of the academy's activity, referred to in Chapter 3, are mentioned below. The bulk of the manuscript is in Latin except for a few passages in Polish (for instance the document granting full powers to Zamoyski). The handwriting in the first section is neat, whereas it becomes muddled in the second. Pages 1-8 contain a copy of the privilege of Sigismund III, which includes the deeds of foundation of the academy, and a second copy of the same material is transcribed on pages 9-17. Pages 19-46 contain fragments of the deeds of the academy dating to 1610, 1612, 1618, 1619 and 1629. These concern decisions regarding the management of the academy and the resolution of disputes. Pages 47-64 contain fragments related to the statute of the academy. Pages 65-68 are entitled 'Vocatio prima professorum ad Academia Zamoscensem' 
The deeds of foundation occupy the first part of the codex and illustrate the educational structure of the institution. As in Sturm's gymnasium this was divided into two levels: the first, known as classes inferiores lasted five years and paved the way to the classes superiores, the second, strictly university level, extending over a period of six years. ${ }^{33}$ There was a total of ten chairs, three for the preparatory level and the others for the advanced classes. The three subjects addressed in the classes inferiores were an introduction to philosophy and eloquence, understood as a single subject, spelling and syntax. The spelling and syntax was not restricted to the classical languages but also extended to Polish, as in the Jesuit university of Vilnius. ${ }^{54}$

The seven disciplines taught in the classes superiores comprised a revised form of the quadrivium, preparing the youths in four fields of knowledge: mathematics, logic and metaphysics understood as a single subject, eloquence, natural philosophy and medicine. ${ }^{55}$ However, at the end of this phase of education the students did not go on to study philosophy and theology, as was the practice in the mediaeval schools after the quadrivium, or to the reading of the Holy Scriptures, as at the Jean Sturm Gymnasium. Since the aim of the Zamość school was to train the young men for political praxis, the most advanced stage of the education was - as specified in the deeds - devoted to study of moral and political philosophy, civil law, especially Roman, and Polish law. The deeds specify that ten professors were assigned to the teaching, one of whom must have dealt with basic training in philosophy and rhetoric, while the other seven were assigned as follows: 'one to teach civil law; another to teach Polish law,

and bear the transcription of the deed awarding Jan Zamoyski full powers, followed by three letters relating to the arrival of the first teachers at the academy. Pages $69-85$ contain the Anacephaleosis professorum Academiae Zamoscensis, a list of all the professors appointed from 1595 to 1714 with details of their education, the date of arrival at the academy, the teaching performed and the positions held, up to and including the place and date of death. In a long note Wadowski reproduces (Anacephaleosis professorum, 77-80) the version of the deeds of foundation on pages $1-7$, considering it to be successive to that contained in pages 9-17 and hence closer to the definitive organisation of the school. Henryk Gmiterek, "Uroczystości akademickie w Zamościu w XVI-XVIII wieku," [Academic celebrations in Zamość between the 16th and 18th centuries], Annales Universitatis Mariae Curie-Sktodowska, 1999/200o, LIV/LV (Section F, Historia), 149-158; Id., "Początki Akademii Zamojskiej," [The beginnings of the Akademia Zamojska], in Piotr Kondraciuk, Jerzy Kuśnierz, Andrzej Urbański (eds.), Jan Zamoyski wódz-mecenas-polityk 1542-1605 [Jan Zamoyski chief-patron-politician 1542-1605] (Zamość: Muzeum Zamojskie, 2005), $73^{-82 .}$

54 Anacephaleosis professorum, 77, and Annex, 144, 148.

55 For a comparison see David L. Wagner (ed.), The Seven Liberal Arts in the Middle Ages. (Bloomington: Indiana University Press, 1983); Olga Weijers, Etudes sur la Faculté des arts dans les universités médiévale: recueil d'articles (Turnhout: Brepols, 2011). 
a third for moral philosophy, a fourth for physics and medicine, a fifth for logic and metaphysics, a sixth for mathematics, a seventh for rhetoric and a seventh for rhetoric... The eighth professor, who shall teach the foundations of philosophy and rhetoric and the classical authors ...; the ninth, who will teach prosody and syntaxis ... like the last teacher of analogy and orthography.'56

At both levels exams were held twice a year, in May and October; students who passed were admitted to the next class. Throughout their schooling all students were personally supervised by a tutor who monitored their progress in Greek and Latin, also acting as an adviser for the other subjects and for more general matters related to school life. In addition to the figure of the tutor, the regulations also included a series of punishments for students who were undisciplined or simply ill-mannered. Mostly the sanctions consisted of monetary fines, but detention and even expulsion were also contemplated. The times of the lessons are also indicated, revealing an intense timetable with lessons from morning through to late afternoon, also including activities in holiday periods. There are also some details of the masters' salaries, which varied depending on the subject taught. Finally, a most interesting aspect is that the document also specifies which books by which authors are to be used in the various classes, just as Sturm did in the Memorandum and De literarum ludis recte experiendis. ${ }^{57}$

According to the Statute youths of all ages were accepted at the school, and after sitting an exam they were admitted to the class most appropriate to their level of preparation. In the first class the pupils started by learning how to read and write in Polish; as stated in the deeds, on their desks there was to be a copy of a book by Jan Kochanowski. Considering the subject, this must definitely have been the Orthographia polska, an adaptation of the Latin alphabet to Polish which was printed in 1592 in Lviv inside a popular treatise on grammar by Jan Ursyn Niedźwiecki (Ursinus, c. 1562-1605), who shortly after its printing was summoned to the academy as a teacher. ${ }^{58}$

After this, the students were introduced to Latin and Greek, spending much of their time studying the grammar. To master the first rudiments of Latin the indicated writers were 'D. Augustini et Donati,' that is Saint Augustine and Aelius Donatus. It is probable that the work of the Roman grammarian Donatus

\footnotetext{
56 Anacephaleosis professorum, 77, Annex, 147.

57 Juanita Feros Ruys, John O. Ward, and Melanie Heyworth (eds.), The Classics in the Medieval and Renaissance Classroom. The Role of Ancient Texts in the Arts Curriculum as Revealed by Surviving Manuscripts and Early Printed Books (Turnhout: Brepols, 2013).

58 Edward Stankiewicz, Grammars and Dictionaries of the Slavic Languages from the Middle Ages Up to 1850 (Berlin, New York, Amsterdam: Mouton Publishers, 1984), 33-44: 35. See also Chapter 3, 1.2 below.
} 
used in class was the Ars minor, whereas it is not easy to understand which of Augustine's works the deeds are referring to. It may have been the Ps. Aurelii Augustinii regulae, or the Ars sancti Augustini pro fratrum mediocritate breviata, better known as the Ars breviata. Scholars have at length doubted the authenticity of both works, but since the mid-1980s it has been possible to establish that Augustine wrote only the Ars breviata. ${ }^{59}$ In any case, a printed volume of the Regulae could have been available in the academy, since the first edition was printed in 1491, but only a manuscript version of the Ars breviata, since this was never printed until $185^{2} .{ }^{60}$

To familiarise themselves with Greek the students used the texts of 'Gaza et Lascare.' Here the reference is certainly to the Grammatica of Theodorus Gaza, in one of the various sixteenth-century editions ${ }^{61}$ and the equally famous work by Constantine Lascaris. From the third year and for the two following, rhetoric and ancient history were added to the subjects of study. Regarding the first approach to rhetoric, two classic textbooks of the time were cited: the Rhetorica ad Herennium and the Progymnasmata by the Greek rhetorician Aphthonius. Obviously only hypotheses can be advanced about the editions used. In the first case the students may have read the treatise addressed to Herennius through the printed version edited by Sturm and published by Josias and Theodosius Rihel in Strasbourg in $1557,{ }^{62}$ while the Progymnasmata may have been read in the Polish edition of 1540, published in Wrocław by Andreas Winkler,

59 In the Retractationes $(1,6,6)$ Saint Augustine explained that he had decided to write a treatise on the seven liberal arts during the time of his sojourn in Milan, where he had gone to receive the sacrament of baptism at Easter of the year 387. According to his plan, the text was also to contain a manual of grammar. However, according to the late-ancient and mediaeval manuscript tradition, there are two grammars attributed to Augustine: Ps. Aurelii Augustinii regulae and the Ars breviata. It has been only through the studies of Vivien Law and Ubaldo Pizzani that it has finally been ascertained that Augustine wrote only the Ars breviata: Vivien L. Law, "St. Augustine's De grammatica Lost or Found?, Recherches Augustinienne 19 (1984): 155-183 and Ubaldo Pizzani, "Gli scritti grammaticali attribuiti a Sant'Agostino," in Miscellanea di studi agostiniani in onore di padre Agostino Trapè, osA, Augustinianum 25 (1985): $361-383$.

6o The first publisher of the Regulae was Angelus Ugoletus who printed the text in Parma 1491; a few months later a reprint by Pellegrino Pasquali appeared in Venice, followed by numerous editions over the 16th century. The first printed edition of the Ars breviata was edited by Angelo Mai and entitled De Sancti Augustini nova grammatica and can be found in Nova patrum bibliotheca, 1843-1854, tomus I, 2 (Rome: Typis Sacri Consilii Propagando Christiano Nomini, 1852), 165-181 (the text begins on page 167).

61 Many of these editions also contain another of Gaza's works on grammar, the Liber de mensibus Atticis. The princeps was instead published by Aldo Manuzio in 1495 . USTC 708661 . 
which contains the first Latin translation of the work by Rudolph Agricola, followed by the instructions of the German philologist Petrus Mosellanus. ${ }^{63}$

Study of the techniques of rhetoric and oratory continued through all phases of the youths' education, so that they were progressively able to address increasingly complex texts. In terms of analysis of the Latin models, the letters of Cicero were used alongside anthologies with passages from Catullus, Martial and Terence. The more demanding works cited in the deeds included Aristotle's Rhetoric, De statibus by Hermogenes, De collocatione verborum by Dionysius of Halicarnassus and Cicero's speeches. There were too many editions of these works in circulation to advance any conjectures about them. Sturm himself, for instance, produced several editions of the works of Hermogenes of Tarsus. The treatise of Dionysius of Halicarnassus is an exception, since students must undoubtedly have studied this in the printed version produced in the printing works of the academy, which is also the first edition to present the Latin version of the text.

History was studied in parallel with rhetoric in the academy but the deeds provide little information about this, indicating only that the students must address both Greek and Latin writers, starting with the works of Herodotus and Thucydides and moving on to Livy. ${ }^{64}$ The reference books for history include a Historiam by Sulpicius Severus, also known as the 'Christian Sallust,' and author of the Chronicle, an account of Christian history from the beginning of the world up to $400 \mathrm{AD}$. The students may have been able to handle the princeps, printed by Oporinus in Basle and edited by the reformer Matthias Flacius, who after fleeing from Venice stayed in Basle for just one year in 1556 before becoming an eminent theologian and professor at Wittenberg. It is, however, more likely in chronological and geographical terms that the edition used in Zamość was that with commentary by Zamoyski's master and friend, Carolus Sigonius (c. 1520-1584), who had penned seminal works on Roman and Jewish history, was an admirer of Cicero and commentator of Livy ${ }^{65}$ In Bologna in 1581 he published an annotated edition of Severus' Chronicle, which also

63 Gerda C. Huisman, Rudolph Agricola. A Bibliography of Printed Works and Translations (Nieuwkoop: B. de Graaf, 1985).

64 Anacephaleosis professorum, 78, Annex, 145, 149.

65 Chapter 2 contains further information on Zamoyski's visit to Padua and the contents of his book, De senatu Romano see note 74. On Sigonius see William McCuaig, Carlo Sigonio: The Changing World of the Late Renaissance (Princeton: Princeton University Press, 1989); Guido Bartolucci, "Carlo Sigonio and the Respublica Hebraeorum: A Re-evaluation," Hebraic Political Studies 3 (2008), 19-59; id., "Historian Engagé. Republicanism and Oligarchy in Carlo Sigonio's Political Histories," Storicamente 8 (2012): 1-6. 
appeared in the lavish collection of the historian's works printed by the Wechel heirs in Frankfurt in $1593 .{ }^{66}$

The department of natural sciences had a vast study programme, including science, geography, astronomy and music. The texts used naturally comprised Euclid's Elements and the works on arithmetic and music by the Byzantine Michael Psellos (1018-1096). Students also read the works of Gemma Frisius (1508-1555), the Sphaera of Proclus and the astronomical treatise Phaenomena by Aratus which deals with the stars, weather forecasts and the impact of celestial phenomena on people. The astronomy and geography course included De chorographia by Pomponius Mela (flourished c. 43 AD), and works by the Austrian Georg von Peuerbach (1424-1461). For physics and medicine the reference texts were Galen's Ars parva, addressing methodological issues, and the Descriptio universae naturae by the Aristotelian Jacques Charpentier (1521-1574). Charpentier's presence in the study programmes of the school is partly due to Zamoyski's first stop on his educational travels in Europe as a youth, namely Paris. He spent four years in Paris between 1555 and 1559, and although he was still an adolescent he was still able to attend some lectures at the Collège de France where his masters included, for philosophy, Charpentier and his bitter enemy Petrus Ramus (1515-1572), Adrien Turnèbe (1512-1565) for classical literature and Jean Pena (?-1558) as a teacher of mathematics. ${ }^{67}$

66 The two editions are, respectively: B. Sulpicii Seueri Bituricensis episcopi Sacrae historiae libri II. In eosdem Caroli Sigonii commentarius. Eiusdem de temporibus Hebraeorum catalogus. Index rerum in vtrunque copiosus (Bononiae: apud Societatem Typographiae Bonon, 1581) (in $8^{\circ}$ ) and Caroli Sigonii De antiquo iure ciuium Romanorum, Italiae, prouinciarum, ac Romanae iurisprudentiae iudiciis, libri 11. Eiusdem, De republica Atheniensium, eorumque ac Lacedaemoniorum temporibus, libri quinque. Quibus adiecti nunc sunt eiusdem De republica Hebraeorum, libri septem: et In B. Sulpicij Seueri historicos libros duos, commentarij duo. Addita in fine anacephalaeosi chronologica historiarum Sulpicianarum (Francofurti: apud heredes Andreae Wecheli, Claudium Marnium, \& Ioan. Aubrium, 1593) $\left(\right.$ in $2^{\circ}$ ). For an overview of Severus' work and the commentary of Sigonius see Paolo Prodi, "Storia sacra e controriforma. Nota sulle censure al commento di Sigonio a Sulpicio Severo," in Piergiorgio Parroni (ed.), Annali dell'Istituto Storico Italo-Germanico 3 (1977): 75104; Piergiorgio Parroni (ed.), Sulpicii Severi chronica (Turnhout: Brepols, 2017), I-XXXIX.

67 The information is taken from the most famous history of the Polish nobility, published in Kraków in 1584: Bartosz Paprocki, Herby rycerstwa polskiego na pięcioro ksiag rozdzielone [The coats of arms of the Polish knights in five books] (Kraków: Maciej Garwolczyk, 1584), modern edition by Kazimierz Józef Turowski (Kraków: Nakl. Wyd. Biblioteki Polskiej, 1858), 26o); Jean Pena taught mathematics in 1557 and 1558, Petrus Ramus gave lectures of Greek and Latin philosophy from $155^{1}$ to 1572, while Adrien Turnèbe taught Greek from 1547 to 1561, see Abel Lefranc, "Liste des lecteurs et professeurs du Collège de France," in Collège de France (1530-1930) (Paris: Les Presses universitaires de France, 1932), 15, 18, 21; Barycz, Pod urokiem, and again Chachaj, Studia zagraniczne, 35-52: 37-38. 
The role played by the mathematical sciences within the curriculum of the school certainly deserves a circumstantiated study. While major attention was given to mathematics in the academic world in the second half of the sixteenth century, there were also substantial differences between the various universities regarding its status within the study programmes. For instance, in the Italian and German universities mathematics was generally part of the course of medicine, while in Paris and Oxford it was included in the teaching of theology. Considering the programme of mathematical sciences proposed at Zamość, we should remember that there was no theology faculty in the early years of the school's activity. This would lead us to assume that mathematics was linked to medical studies or enjoyed independent status as at the nearby University of Kraków. This university was in fact the first institution in Europe - as early as the beginning of the fifteenth century - to have created a chair of mathematics independent of other disciplines, providing a solid education to a generation of brilliant mathematicians. Conrad Celtis (1459-1508) was trained here between 1488 and 1490, after which he went on to spread the knowledge acquired in the Universities of Ingolstadt and Vienna. In the following chapter we shall also see how one of the most illustrious mathematicians of the time, Adriaan van Roomen (Adrianus Romanus, 1561-1615), taught for a short while at the Akademia Zamojska, making constant visits to Kraków where he engaged in scientific debates with his Polish colleagues. ${ }^{68}$

Although it is a decidedly fascinating topic, to date it has not been possible to clarify how the teachers of the Akademia intended to apply mathematics to the practice of statecraft. The most complex aspect of such an investigation would definitely concern the link between mathematics and logical-philosophical doctrines. Conversely, it does not seem rash to argue that mathematics may have enjoyed special attention in view of its application and utility in the sphere of military science, which was naturally addressed in the school. Mathematical and geometrical studies provided grounding in the nature of fortifications, the rules of ballistics, the positioning of troops on the battlefield and cartographic representations, none of which could be neglected in the education of a good statesman.

The deeds of foundation do not mention any theology faculty, and hence there is no information about books or authors used for this subject. What they do record is that the Bishop of Chełm, Jerzy Zamoyski (1565-1621), decided to set up a chair of theology and one of canon law, but that his plan was never carried through. The subject was then introduced into the curriculum of the school via several passages of a diplomatic nature which involved the 
bishopric on one side and the school on the other in the first twenty years of the seventeenth century. Indeed it should be remembered that in Zamość a collegiate church had been built between the academy and the church which, while on the one hand guaranteeing religious observance to the community and the performance of the various functions, in effect divested the bishop of the same and hence diminished his direct influence over the academy. Furthermore, some of the teachers were sagely summoned to act as canons in the collegiate church, so that they could exert themselves to keep a balance between the bishop's wishes and the lay character of the school. Although they succeeded in safeguarding the independence of the latter for several decades, they must have been under considerable pressure since in 1617 Pope Paul v had to intervene. He issued a bull endorsing the fact that only the heirs of Jan Zamoyski, namely his son Tomasz and not the bishop, had the right of decision over the school. The difficult balance of power nevertheless deteriorated and was irreparably undermined when, on 24 November 1638 , the founder's daughterin-law Katarzyna Zamoyska (1602-1642) decided to summon four vicars and four canons to the chapter of the collegiate. This shortly led to the creation in 1640 of what was, to all effects and purposes, a seminary. Subsequently, on 26 September 1648, Pope Innocent $x$ established that theology was from then on to be the fourth faculty of the academy, alongside law, philosophy and arts. ${ }^{69}$

\section{Doctoral Studies}

As we have seen, at least in its initial intentions, at the Akademia Zamojska particular attention was devoted to the education of the youths in classical literature, the national language and rhetoric, alongside a considerable offer in the fields of medical sciences and mathematics. However, it could not award doctorates in these subjects since its privileges permitted only the graduation of doctors in law and in philosophy. The student intending to study jurisprudence up to the most advanced level was expected to start from an indepth knowledge of the Institutiones of Justinian, one of the four parts of the

69 See Łempicki, Działalność Jana Zamoyskiego, 170-171; Bolesław Kumor, "Wydział teologiczny Akademii Zamojskiej (1648-1784)," [The faculty of theology of the Akademia Zamojska (1648-1784)], in Ryszard Szczygieł, Andrzej Urbański (eds.), Akademia Zamojska w dziejach i życiu miasta [The Akademia Zamojska in the history and life of the city] (Zamość: Muzeum Okręgowe w Zamościu, 1996), 67-68. More specifically see Marzena Hanna Dyjakowska, "Wyznaniowy charakter Akademii Zamojskiej (1594-1784)," [The religious character of the Akademia Zamojska (1594-1784)], Studia z Prawa Wyznaniowego [Studies on canon law] 3 (2001): 51-76. 
Corpus juris civilis in which the Roman emperor reorganised the rules underlying Roman law. The other texts of the Corpus also appear in the syllabus. In fact, the lessons began at 9 a.m. in the morning with the Institutiones and later the students studied the Pandectae, the Codex and the not otherwise specified 'tituli perpetui.'

Sixteenth-century Polish juridical and political literature contains various examples of reflection on the role of Roman law in the establishment of Polish law. Among the writers particularly interested in the subject were Jan Ostroróg (1436-1501), Andrzej Frycz Modrzewski (1503-1572) and Jakub Przyłuski (c. 1512-1554). It should also be remembered that the urban bourgeoisie, frequently the wealthiest part of the population, was also very interested in Roman law. They saw it as primarily an instrument for reorganising municipal law, a vision confirmed and analysed in the treatises of jurists including, for instance, Jan Jelonek Cervus z Tucholi (Ioannes Cervus Tucholiensis, c. 1500-c. 1557) and Jan Kirstein Cerasinus (1507-1561). The dual intention in the application of Roman law to the government of the territory was both to strengthen and to standardise Polish municipal law, which since the Middle Ages had been based on the rules of Saxon-Magdeburg law. ${ }^{70}$

Nevertheless, despite the considerations of various jurists and political thinkers, it has to be said that the study of Roman law was not very common in the Commonwealth at the end of the century, and more importantly was not appreciated by the aristocratic Polish elite. While in Germany, Italy and southern France it was one of the most important components of the study of law and was taught using the same methodological approach, the Polish nobility unlike the bourgeoisie - considered it to be just one more instrument in the

$70 \quad$ Władysław Bojarski, Jan Jelonek Cervus z tucholi i jego twórczość prawnicza (z dziejów prawa rzymskiego $w$ Polsce). Prawo prywatne materialne [Jan Jelonek Cervus da Tuchola and his works on law (on the history of Roman law in Poland). Private Law] (Toruń: Uniwersytet Mikolaja Kopernika, 1989); Władysław Bojarski, Zbigniew Nawrocki, Jan Jelonek Cervus z tucholi i jego twórczość prawnicza. Ustrój sąów i prawo procesowe [Jan Jelonek Cervus da Tuchola and his works on law. The judicial system and procedural law] (Toruń: Uniwersytet Mikolaja Kopernika, 1993); Lesław Pauli, Jan Kirstein Cerasinus (1507-1561), krakowski prawnik doby Odrodzenia: studium z dziejów praw obcych i literatury prawniczej $w$ Polsce [Jan Kirstein Cerasinus (1507-1561), a Kraków lawyer in the Renaissance: studies on the history of foreign legal systems and juridical literature in Poland] (Kraków: Państwowe Wydawn. Nauk., Oddz. w Krakowie: Nakł. Uniwersytetu Jagiellońskiego, 1971). On the roots of Saxon and Magdeburg Law in Poland see Inge Bily, Wieland Carls, Katalin Gönczi (eds.), Sächsisch-magdeburgisches Recht in Polen. Untersuchungen zur Geschichte des Rechts und seiner Sprache (Berlin: De Gruyter, 2011). 
hands of the sovereign to reinforce his powers. ${ }^{71}$ For this reason, the subject was at times given little attention in the schools, including the prestigious Jagiellonian, which included it in the curriculum later than other European universities, in 1518 . The first chair was established only in 1533 and entrusted to the bishop Piotr Tomicki (1523-1536), ${ }^{72}$ who had graduated in law at the University of Bologna, which had traditionally specialised in the study of Roman law since the eleventh century in view of its famous school of glossers. ${ }^{73}$

71 There are numerous studies on the teaching of law in the sixteenth century, here I refer only to Jacques Krynen, Michael Stolleis (eds.), Science politique et droit public dans les facultés de droit européennes (XIIIe-XVIIIe siècle) (Frankfurt am Main: Klostermann, 2008). For the history of the teaching of Roman law in Poland in the early modern period, see Władysław Bojarski, "Droit romain comme matière de l'enseignement en Pologne au XVI ${ }^{\mathrm{e}}$ siècle," in Profesorowi Janowi Kodrębskiemu in memoriam [For professor Jan Kodrębski. In memoriam] (Łódź: Wydawn. Uniw. Łódzkiego 200o), 9-25. For the role of the Jagiellonian University apropos this discipline, the studies of Janusz Sondel are fundamental; among the most recent see: "Prawo rzymskie na Uniwersytecie Jagiellońskim od reformy Kołłataja do 1945 roku," [Roman law at the Jagiellonian University from the reform of Kołłątaj to 1945], in Studia z historii ustroju i prawa [Studies on the history of the political and legal system] (Poznań: Printer, 2002), 347-381; "Prawo rzymskie na Uniwersytecie Krakowskim w okresie Oświecenia," [Roman law at the University of Kraków during the Enlightenment], in $Z$ dziejów kultury prawnej [On the history of the legal culture] (Warsaw: Liber, 2004), 225-256. As regards the teaching of law at the academy of Vilnius and in Danzig, see Piotr Niczyporuk, "Nauczanie prawa rzymskiego w Akademii Wileńskiej," [The teaching of Roman law at the Academy of Vilnius], in Adam Lityński, Piotr Fiedorczyk (eds.), Wielokulturowość polskiego pogranicza. Ludzie-Idee-Prawo [Multiculturalism in borderland Poland. People-ideas-law] (Białystok: Wydawnictwo Uniwersytetu w Białymstoku, 2003), 145-162 and Jacek Dmowski, "Nauczanie prawa rzymskiego w Gdańsku od XVII do XIX wieku," [The teaching of Roman law Danzig from the 17 th to the 19th century], Gdańskie Studia Prawnicze [Danzig legal studies] 1 (1997): 63-65.

72 Roman law was also taught in Kraków in the sixteenth century by Jan Jelonek z Tucholi (Joannes Cervus Tucholensis), Jan z Turobina (1511-1575) and Jakub Karwińczyk (Charvinius). On this argument see Marek Kuryłowicz, Prawo rzymskie: Historia, tradycja, wspótczesność [Roman law. History, tradition, topicality] (Lublin: Wydaw. Uniwersytetu Marii Curie-Skłodowskiej, 2003); Antoni Dębiński, "Prawo rzymskie a kultura prawna w Polsce," [Roman law and legal culture in Poland], in Tadeusz Guz, Jan Głuchowski, Maria R. Pałubska (eds.), Synteza prawa polskiego od 1989 roku [A synthesis of Polish law from 1989] (Warsaw: Wydawnictwo C.H. Beck, 2013), 3-10.

73 The famous work of the Quattuor Doctores of Bologna who rediscovered and annotated Justinian's Corpus iuris civilis boasts a huge bibliography. For a general overview I refer to just one recent contribution Charles Radding (ed.), The Corpus iuris civilis in the Middle Ages: Manuscripts and transmission from the sixth century to the juristic revival (LeidenBoston: Brill, 2007). For the history of the Corpus iuris civilis in the sixteenth century, see Hans Erich Troje, Graeca leguntur. Die Aneignung des byzantinischen Rechts und die Entstehung eines humanistischen Corpus iuris civilis in der Jurisprudenz des 16. Jahrhunderts (Cologne/Vienna: Böhlau, 1971). 
From its beginnings the university also hosted a community of Polish students who continued to be a constant presence even in the following centuries, including for instance the aforementioned Jan Jelonek Cervus, who graduated there in 1459, and Jan Ostroróg who qualified the following year. ${ }^{74}$

Zamoyski was determined to fill this gap in the national scholastic curricula, probably recalling how this training had stood him in such good stead in his later political career. He had been a brilliant student of law in Padua, where his teachers included jurists of international renown such as Marco Mantova Benavides (1489-1582), Guido Panciaroli (1523-1599) and Tiberio Deciani (1509-1582). Another of his masters, Carolus Sigonius, played a particularly decisive role in Zamoyski's education, even supervising him in the preparation of the De senatu Romano libri duo which was the most mature result of his juridical studies, published in Venice by Giordano Ziletti (Jordanus Zilettus, fl. $1549-1583$ ) in $1563 .{ }^{75}$

Up to the middle of the seventeenth century education in Roman law retained a prominent position inside the academy, after which it entered into a phase of stagnation. Studies in the field then acquired new stimulus in the middle of the eighteenth century as a result of the teaching and writings of one of the masters, Wawrzyniec Józef Żłoba $(1739-1804) \cdot{ }^{76}$ Evidence of the

74 In the 11th century the Poles sojourning in Bologna were almost all ecclesiastics; by the

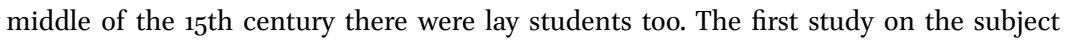
was by Carlo Malagola, "I Polacchi in Bologna," in Bologna. Album-storico (Bologna: Successori Monti, 1882), 17-38. On Polish students in Bologna in the mediaeval period, see also: Adam Vetulani, "Z badań nad Polakami w średniowiecznej Bolonii," [Research on the Poles in mediaeval Bologna], in Stefan Krzysztof Kuczyński (ed.), "Cultus et cognitio." Studia z dziejów średniowiecznej kultury ['Cultus et cognitio:' Historical studies of mediaeval culture] (Warsaw: Państw. Wydawn. Nauk, 1976), 611-619. Also see Zofia KozłowskaBudkowa, Celina Zawodzińska, "I primi studenti polacchi all'Università di Bologna (fino al 1364)," in Commentationes historicae. Almae Matri Studiorum Bononiensi novem saecula feliciter celebranti ab Universitate Iagellonica Cracoviensi oblatae (Warsaw-Kraków: Universitas Iagellonica, 1988), 27-48. For a general overview see Stanisław Kot, Le relazioni secolari della Polonia con Bologna (Bologna: Istituto per la Storia Dell'Università, 1949). The most recent contribution, comprising a complete bibliography on the subject, is Stanisław A. Sroka, "Academic degrees obtained by Poles studying at Northern Italian universities in the second half of the 15th c. (Bologna, Padua, Ferrara)," Annali di Storia delle Università italiane 17 (2013): $325^{-332 .}$

75 Ioannis Sarii Zamoscii De senatu Romano Libri Duo (Venetiis: apud Iordanum Ziletum, 1563), in $4^{\circ}$. For a modern edition of the work complete with historical and juridical commentary see Marek Kuryłowicz and Wojciech Witkowski (eds.), Rozprawa Jana Zamoyskiego o senacie rzymskim [Jan Zamoyski's dissertation on the Roman Senate] (Lublin: Wydaw. Uniwersytetu Marii Curie-Skłodowskiej, 1997).

76 Marek Kuryłowicz, "Prawo rzymskie w studiach i koncepcjach akademickich Jana Zamoyskiego," [Roman law in the studies and academic concepts of Jan Zamoyski], in Henryk Gmiterek (ed.), W kręgu akademickiego Zamościa [In the milieu of the academy of 
ascending and descending parabola of the teaching of Roman law in the early decades of life of the school are the number (around 30) and arguments of the theses defended by the law students, some of which were printed in the school's publishing house, with the first recorded dating to $1603 .{ }^{77}$

On the other hand, the theses did not deal only with the Corpus iuris civilis, since the programme described in the deed of foundation also scheduled, in the afternoon, study of the 'Jus feudorum,' in which 'Juris Saxonici et Magdeburgensis a quo fere id fluxit origines demonstrabit.' As mentioned above, this was a body of legal provisions on which the municipal law of the Commonwealth was modelled, so that study of it was crucial for training the students in political practice. Based on the few details specified in the deeds, it seems likely that the teaching involved analysis of the treatises of Konrad Lagus of Danzig (c. 1499-1546) who expounded the Magdeburg Law (Magdeburger Recht) and the Saxon law (Speculum Saxonum, 'Saxon mirror'). However, the apex of the studies of jurisprudence appears to have been national law, which was a complete novelty in Poland at the time. Indeed, for the first time in history this became the subject of a university course, comprising examination of the laws, the legal systems and the structure of the chanceries. ${ }^{78}$

Zamość] (Lublin: Wydawnictwo Uniwersytet Marii Curie-Skłodowskiej, 1996), 95-112, esp. 111-112. See also the first chapter of Marzena Dyjakowska, Prawo rzymskie w Akademii Zamojskiej w XVIII wieku [Roman law at the Academy of Zamość in the 18th century] (Lublin: Redakcja Wydawnictw KUL, 2000).

77 On the law theses defended and published in the school see Marzena Dyjakowska, "Badania porównawcze nad Corpus Iuris Civilis i ustawodawstwami obcymi w pracach profesorów Akademii Zamojskiej," [Comparative studies on the Corpus Iuris Civilis and foreign legal systems in the works of the professors of the academy of Zamość], in Starożytne kodyfikacje prawa [Ancient legal codes] (Lublin: Katolicki Uniwersytet Lubelski, 200o), 153-186, Ead., "Comparative research on Corpus Iuris Civilis in dissertations of professor's of Academy of Zamość, Review of Comparative Law 8 (2003): 191-215 and Marian Chachaj, "Czy w XVIII wieku drukowano w Zamościu tezy rozpraw doktorskich z prawa Rzymskiego?," [Were doctoral theses in Roman law published at Zamość in the 18th century?], Czasy Nowożytne 24 (2011): 149-162.

78 The most important contribution is still Marek Kuryłowicz and Wojciech Witkowski, "Nauczanie prawa w Akademii Zamojskiej (1594-1784)," [The teaching of law at the Akademia Zamojska (1594-1784)], Palestra 7 (1980): $38-56$. There is also a French version of this article: "L'Académie de Zamość, une école de droit en Pologne, du XVI e au XVIII e siècle," Revue historique de droit français et étranger, Quatrième série 63 (octobre-décembre 1985), No. 4: 499-511. See also Marek Kuryłowicz, "Nauczanie prawa w Akademii Zamojskiej w świetle wybranych tekstów źródłowych," [The teaching of law at the Akademia Zamojska in the light of selected textual sources], in Pomniki prawa doby Renesansu w Europie Środkowo-Wschodniej, Łacina w Polsce [Monuments of law in central-eastern Europe in the Renaissance. Latin in Poland], fasc. 7-9 (Warsaw: овтA, 1999), 191-248. 
The other subject in which the academy could confer degrees was philosophy. As mentioned above, in the classes inferiores this was taught in a preparatory manner along with certain rudiments of rhetoric. The course was begun by the Professor elementorum Philosophia ac Rhetorica humaniorumque literarum, who introduced elements of philosophy based on the second book of Cicero's Academica. ${ }^{79}$ As known, there were two editions of this Ciceronian dialogue, the first consisting of two books and the second of four: all that has survived of the first edition is the second book known as Academica priora and also as Lucullus, while all that survives of the second version, Academica posteriora, is part of the first book. The students attending the classes inferiores concentrated on the first part of the twelve chapters of the Lucullus, which presents a summary of ancient philosophical thought that provided a useful guide to the most important subjects and writers for those unfamiliar with the discipline.

In the classes superiores the philosophical programme became wider and more detailed. The masters taught Aristotle's Metaphysics, Plato's Parmenides and the dialectic of the Stoics. The students also concluded the analysis of the Academica priora, addressing the part in which Cicero tackles the question of knowledge and enunciates the doctrines of probabalism of the new Academy represented by Philo of Larissa and Antiochus of Ascalon. At four in the afternoon ('Hora quarta pomeridiana') the timetable featured Cicero again, this time the second book of De natura deorum, namely the section in which Quintus Lucilius Balbus expounds the Stoic theory about the gods, sustaining that the world is governed by providence. It is interesting to note that in the school timetable this analysis follows the reading of Galen's Ars parva. This was at the

79 A still valid overview of the argument is Izydora Dąmbska, "Filozofia w Akademii Zamojskiej w dobie Renesansu," [Philosophy at the academy of Zamość in the Renaissance], in Szczucki (ed.), Nauczanie filozofii $w$ Polsce $w X V-X V I I I$ wieku [The teaching of philosophy in Poland from the 15th to 18th centuries], 87-114. More recent contributions are by Danilo Facca, concentrating on the teaching of philosophy by certain teachers of the academy: "Kultura późnego Renesansu w nauczaniu filozofii w Akademii Zamojskiej," [Late Renaissance culture in the teaching of philosophy at the Akademia Zamojska], in Świt i zmierzch baroku [Sunrise and sunset of the Baroque] (Lublin: Towarzystwo Naukowe KUL, 2002), 11-24; "Szkolny arystotelizm Adama Burskiego w świetle jego komentarza do Etyki Nikomachejskiej," [The Aristotelianism of the school of Adam Burski in the light of his commentary on the Nichomachean Ethics], Odrodzenie i Reformacja w Polsce [Renaissance and Reform in Poland] 42 (1998): 59-72; "Filosofia e retorica nel commento al Timeo di Szymon Birkowski," Verbum (1999): 48-58; "Philosophical Pedagogy in Early Seventeenth-Century Poland: 'Method' and 'Accumulation' in the Philosophical Teaching of Adam Burski," Acta Comeniana 13 (1999): 83-97; Humanizm ifilozofia w nauczaniu Adama Burskiego [Humanism and philosophy in the teaching of Adam Burski] (Warsaw: Polska Akademia Nauk. Instytut Filozofii i Socjologii, 2000). 
time one of the textbooks most widely used for an introduction to medicine, and we cannot overlook the fact that the author also expresses here an opinion regarding providence which is the opposite of the Stoics, rejecting their divine determinism.

The teachers of practical philosophy ('philosophiae quae de vita et moribus ac de re civili tractat') used primarily Aristotle's Nicomachean Ethics and Politics, Xenophon's Oeconomicus, Plato's Laws and two more works by Cicero, De officis and De Republica. The writer who appears to carry most weight in the philosophical studies is Aristotle, whose works are analysed through the writings of Cicero. Moreover, Cicero was not only a guide in the field of philosophy and a literary and stylistic example: the academy was aligned with sixteenthcentury Polish Ciceronianism, which had elected the Roman thinker as a model in which civil education and political activity had their perfect synthesis. ${ }^{80}$ The students did not study philosophy all year round, since in the summer period it was replaced for recreational purposes by the reading of Greek and Latin poets combined with analysis of Aristotle's Poetics.

The deeds of foundation describe a scholastic type of teaching in which the lectio is based on the practice of reading. The masters direct the students' knowledge of the writers by reading their works and commenting and explaining the key passages. ${ }^{81}$ The scholastic approach is confirmed by the names of the writers cited in the deeds: Donatus for grammar, Aristotle for philosophy, Galen for medicine, Cicero and Quintilian for rhetoric and the Corpus iuris civilis for law.

In addition to the information and instructions detailed in the deeds, the manuscript collection also contains a significant number of documents concerning the teaching activity. Some of these confirm the application of the programme while others indicate changes to the original study plans. To mention just two examples, which will be more fully dealt with in Chapter 3 , the codex BN вOZ 141 contains among other things some details about the teachers' adherence to what was set forth in the deeds. The manuscript comprises copies

8o See the first part of Stanisław Kot, Wptyw starożytności klasycznej na teorie polityczne Andrzeja Frycza z Modrzewa [The influence of classical antiquity on the political theories of Andrzej Frycz Modrzewski] (Kraków: Nakł. Akademii umiejetności, 1911); Tadeusz Bieńkowski, "Cicero, cui omnes cedimus. Uwagi nad znajomością Cycerona w Polsce w $\mathrm{XV}$ wieku," [Cicero, cui omnes cedimus. Observations on the knowledge of Cicero in $15^{\text {th- }}$ century Poland], Meander 15 (1960), 5-6: 263-274; Id., "Z badań nad recepcją literatury antycznej w Polsce w okresie Odrodzenia," [Studies on the reception of ancient literature in Poland during the Renaissance], Odrodzenie i Reformacja w Polsce 11 (1966): 37-48.

81 In general, see Eugenio Garin's classic study, L'educazione in Europa (1400-16oo): problemi e programmi (Rome: Laterza, 1957), 58-63. 
of the Procli sphaera and the Apparatus ad geographiam Pomponii Melae, with respective commentary by the masters Jan Ursinus and Walenty Ptarmius, which were probably used during lessons. ${ }^{82}$ In other cases the manuscript collection helps to supplement the information in the deeds, revealing, for instance, that the teachers of logic liaised with those engaged with both mathematics and eloquence. It also emerges that, as in the other universities of the time, philosophical education was accompanied by the organisation of public debates, and interesting details about these can be found in the manuscript notes of the students. ${ }^{83}$

The correspondence between the study programmes described in the deeds and the editorial production of the academy is similarly interesting. The printing works and the school were very closely connected; especially in relation to doctoral studies, the publishing house appears to have been at the service of the teachers who saw it as a second place of work. Here I shall only briefly mention the printing, in 1601, of the already-mentioned Speculum Saxonum, and of the Farrago actionum iuris civilis in 1607 by the already-mentioned Jan Jelonek Cervus, professor at University of Kraków and expert jurist in both Roman and municipal law. In the field of philosophy, in 1604 the Dialectica Ciceronis was printed; this is a collection of fragments drawn from Cicero's writings centred on the Stoic system of logic which appears to correspond to the need expressed in the deeds to introduce pupils to the 'dialectica Stoicorum.' De collocatione verborum by the Greek rhetorician Dionysius of Halicarnassus, a work explicitly mentioned in the deeds of foundation, was published in the same year.

Obviously the study programmes, the printed works, the books and the manuscripts were anything but separate elements in the life of the academy. The correspondences between them illustrate the modus operandi of the teachers, and reveal the instruments they chose to employ in their work and the methods used in the classroom to stimulate learning. They document the type of educational approach that was implemented to train the students in the practice of statecraft. Throughout the sixteenth century schools and universities were engaged in transmitting bonae litteraes, developing new teaching methods and better-organised study programmes. The flowering of new scholastic institutions was undoubtedly what gave rise to the enormous interest

82 In BN воZ 141 the two works are set forth respectively on ff. 129-137v and ff. 141-218. For a full description of the manuscript see see Chapter 3, I, 3: Rhetoric in the syllabus and in the print shop.

83 Several examples are contained in the manuscript BN воZ 1525 (272 ff., dimensions 21.5xı6.5, microfilm no. 83911). See Dąmbska, “Filozofia w Akademii Zamojskiej," 97. 
in questions of the ordo and methodus of knowledge in both the centres of scholastic tradition, such as the Universities of Padua and Paris, and in the English and Swiss schools of Ramist orientation and the German Reformed schools. ${ }^{84} \mathrm{~A}$ reliable and rational approach was called for that could be pursued by physicians, philosophers and jurists and by those dedicated to all other intellectual professions to prevent them falling into the sterile technicalities of scholasticism. This attempt to produce an effective knowledge process obviously affected the subject of politics too, a new discipline in the university curricula. At Zamość, as in other coeval schools, a strict return to the sources, the structuring of knowledge and the revision of study programmes were crucial stages in the study of politics.

84 See Neal W. Gilbert, Renaissance concepts of method (New York: Columbia University Press, 1960); Daniel A. Di Liscia, Eckhard Kessler, Charlotte Methuen (eds.), Method and Order in Renaissance Philosophy of Nature. The Aristotle Commentary Tradition (Aldershot: Ashgate, 1997). More in general see also Garin, L'educazione in Europa; Grafton, Jardine, From humanism to the humanities. 